\title{
Possibilities of Application Cement By-Pass Dust into the Garden Architecture Elements
}

\author{
Lukáš Procházka, Barbara Vojvodíková *iD and Jana Boháčová (D)
}

Citation: Procházka, L.; Vojvodíková,

B.; Boháčová, J. Possibilities of

Application Cement By-Pass Dust

into the Garden Architecture

Elements. Crystals 2021, 11, 1033.

https://doi.org/10.3390/

cryst 11091033

Academic Editors: Dali Bondar and Shujun Zhang

Received: 15 July 2021

Accepted: 25 August 2021

Published: 28 August 2021

Publisher's Note: MDPI stays neutral with regard to jurisdictional claims in published maps and institutional affiliations.

Copyright: (c) 2021 by the authors. Licensee MDPI, Basel, Switzerland. This article is an open access article distributed under the terms and conditions of the Creative Commons Attribution (CC BY) license (https:/ / creativecommons.org/licenses/by/ $4.0 /)$.
Faculty of Civil Engineering, VSB-Technical University of Ostrava, L. Podeste 1875, Poruba, 70800 Ostrava, Czech Republic; lukas.prochazka@vsb.cz (L.P.); jana.bohacova@vsb.cz (J.B.)

* Correspondence: barbara.vojvodikova@vsb.cz

Abstract: This article deals with the possibility of using cement by-pass dust (CBPD) in the garden architecture elements, specifically in curbs for park use. To increase the positive effect on the environment, other secondary raw materials were also used in the research, specifically blast furnace granulated slag and silica fly ash. Mixtures were based on alkali activation, where cement as a binder was $100 \%$ replaced by raw materials with waste properties. In the research, properties of used materials and also the basic physical-mechanical and durability properties of prepared mixtures were determined Part of the research focused on the effect of the tested beams on the grassland planted around the beams. Any significant negative impact was not registered, except for low $\mathrm{pH}$ increase of soil. Infrared spectroscopy and thermal analysis were performed on selected samples. Testing has shown that the products are in accordance with the Czech standard requirements for concrete curbs in garden architecture. The samples did not pass only the scaling test, which is, however, a condition for concrete curbs used for roads. For garden architecture this test is not required.

Keywords: cement by-pass dust; blast furnace granulated slag; silica fly ash; alkali-activated materials; curb; environmental effects; material engineering

\section{Introduction}

The environmental impacts of the cement industry have been considered, described and assessed many times. Concerns about the environmental consequences of emissionsrelated Portland cement production are growing. Some studies state that the cement industry, if not equipped with the appropriate technologies, accounts for $15 \%$ [1] or up to $40 \%$ [2] of Particulate Matter (PM) emissions from industrial production [1]. High concentrations of particles emitted by cement plants can affect the health of people living near to a cement plant [3]. There is also a negative effect on vegetation around the cement plant [4]. Of the entire production process, the technological part of clinker production is the most significant contributor of pollution [1,5]. During the production of clinker, many dust particles are formed. Kiln dust is released into the air [6]. Many projects have dealt with reducing negative impacts of these cement plants on the environment $[5,7]$. In particular, they focus on technologies reducing emissions. If the appropriate technology is installed, dust particles from different stages of production are captured. This brings another problem to the fore, which is the trapped particles, which are cement kiln dust (CKD) or cement by-pass dust (CBPD). CKD is a fine-grained material contained in the flue gas in a rotary kiln [6]. It consists of a diverse mixture of calcined and non-calcined feed materials, fine clinker, fuel combustion by-products and condensed alkaline compounds [8,9]. When installing a by-pass, the kiln gases are sucked out and, with a rapid cooling, undesired gases condense on the surface of the dust particles (cement by-pass dust CBPD) [10]. This material is a waste product. CKDs are always included in the cement plant system; CBPDs are only obtained under certain conditions if a bypass is installed. Installing a by-pass reduces unwanted impurities such as chlorine and alkali. The quality of CBPD depends mainly on the combustion technology, the raw materials and the fuel used [11,12]. 
CBPDs are characterized by a variety of chemical, mineralogical and physical properties. In comparison with CKD, CBPDs are characterized by high concentrations of chlorine. Additionally, the content of potassium and sulphur dioxide can be up to 2-2.5 times higher $[13,14]$. CKDs can contain a large amount of free lime, which is why they can be used as fertilizers or for stabilizing sewage sludge [8]. CKD can also be used as an alkaline activator for pozzolanic or latent hydraulic materials.

CBPD is used less. Reuse in cement production is prevented by the high content of alkalis and sulphates. The production of CBPD incurs a loss for the cement companies since most of the material is landfilled $[8,15]$.

The main goal of the GeoDust research was to find a possible use of CBPD in industrial production. One of the partial goals was to use CBPD in the production of elements of garden architecture, specifically curbs.

To increase the positive effect on the environment [16], input raw material, slag, fly ash and CBDP were used for alkaline activation in the research. As a result, cement was $100 \%$ replaced by raw materials with waste properties as a binder.

The uniqueness of this research lies in the comparison of properties in in situ testing: placing the test elements to real weather conditions in situ and monitoring the environmental impact of the elements.

This group of materials has been extensively studied in recent decades. In the context of the use of different input materials with different chemical and physical properties, significant structural, mechanical and physical differences were found in the resulting alkali-activated materials. The resulting products also depend on the type and amount of activator used [17-19]. During alkaline activation of slag, calcium is dissolved and aluminum participates in the formation of C-(A)-S-H gel [17,20-26]. The properties of alkali-activated aluminosilicates are affected by the formation of a three-dimensional gel of the N-A-S-H type $[17,18,20,22-25,27,28]$. Although quality results can be achieved from both types of materials (slag, fly ash), these materials also have several disadvantages such as rapid setting and high shrinkage in alkali activated slag $[20,24,29]$ and, in fly ash, a requirement for curing at elevated temperature and long setting times $[20,24,25,30]$. The research examined the possibility of reducing the above disadvantages by combining input materials with mixed alkali-activated materials in the system $\mathrm{Na}_{2} \mathrm{O}-\mathrm{CaO}-\mathrm{Al}_{2} \mathrm{O}_{3}-$ $\mathrm{SiO}_{2}$, which would lead to improved setting time, workability, shrinkage and mechanical durability properties [20]. When the addition of slag to fly ash accelerates the setting, in contrast, the retardation of the setting of alkali-activated slag (even in combination with fly ash) can be achieved by adding phosphoric acid. The acid reacts with calcium ions to form $\mathrm{Ca}_{3}\left(\mathrm{PO}_{4}\right)_{2}$, which reduces the content of calcium ions and thus slows down the formation of C-S-H gels [31,32]. The resulting hydration products in mixed systems are based on C-A-S-H, N-A-S-H and (N-C)-A-S-H gels [17,20,24,28]. When the reactions of mixed alkali-activated systems occur at normal temperatures $\left(27^{\circ} \mathrm{C}\right)$, the reaction of blast furnace slag is dominant and C-A-S-H gel-type products are formed $[23,25]$.

\section{Materials and Methods}

\subsection{Materials}

\subsubsection{Silica Fly Ash (Fa)}

In the experiment, fly ash from the power plant in Ostrava-Třebovice, silica fly ash after denitrification by the SNCR method and ground fly ash with the surface area of $500 \mathrm{~m}^{2} / \mathrm{kg}$ was used. The percentages of individual oxides obtained by a fluorescence spectrometer measurement are shown in Table 1 . The content of ammonia released from the aqueous extract is $22.8 \mathrm{mg} / \mathrm{kg}$. The mineralogical composition of the fly ash used was determined by X-ray diffraction. Figure 1 shows that $\mathrm{SiO}_{2}$ occurs in this fly ash mainly in the form of quartz. Other minerals represented in this fly ash include Mulite, Magnetite, free lime and Hematite. This fly ash did not show a typical arc for the amorphous phase [33], so it can be assumed that this fly ash has low reactivity, which corresponds to the finding in [34] where 
the soluble amorphous phase content determined by cooking in $4 \mathrm{M}$ potassium hydroxide solution was only $4.17 \%$.

Table 1. Content of selected oxides in input raw materials. (FA—fly ashes, LOI—Loss on Ignition).

\begin{tabular}{cccc}
\hline & & Content $[\%]$ & \\
\cline { 2 - 4 } Oxide & FA & BFS & CBPD \\
\hline $\mathrm{SiO}_{2}$ & 50.89 & 33.81 & 5.32 \\
$\mathrm{Al}_{2} \mathrm{O}_{3}$ & 21.34 & 8.14 & 1.46 \\
$\mathrm{Fe}_{2} \mathrm{O}_{3}$ & 9.49 & 0.32 & 1.22 \\
$\mathrm{CaO}$ & 4.48 & 46.16 & 34.08 \\
$\mathrm{SO}_{3}$ & 0.58 & 1.46 & 5.16 \\
$\mathrm{~K}_{2} \mathrm{O}$ & 3.14 & 0.42 & 18.62 \\
$\mathrm{MgO}$ & 1.67 & 7.86 & 0.48 \\
$\mathrm{LOI}$ & 6.27 & 0.00 & 21.90 \\
\hline
\end{tabular}

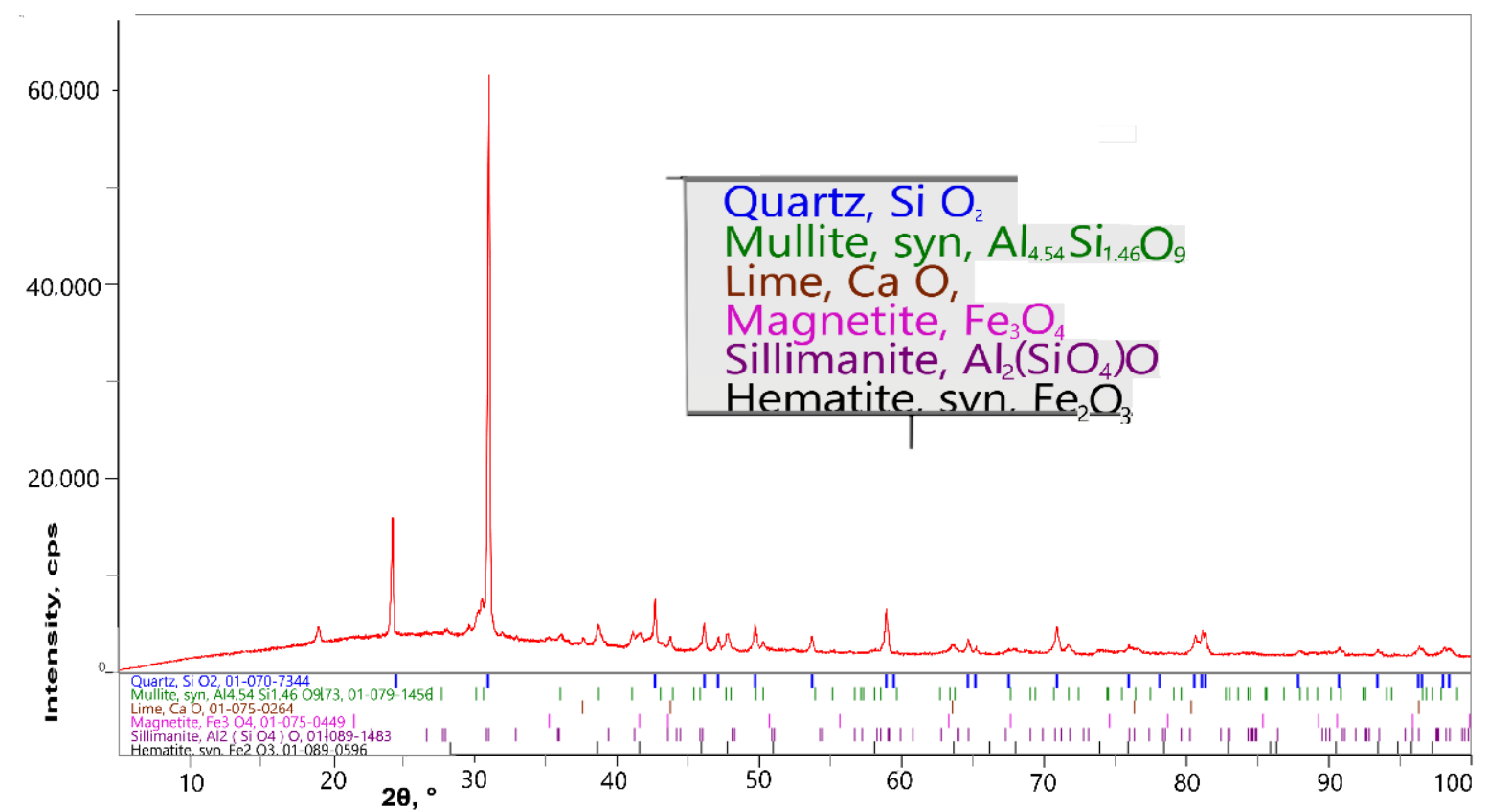

Figure 1. Mineralogical composition of FA determined by X-ray diffraction (XRD).

\subsubsection{Blast-Furnace Granulated Slag (Bfs)}

For the experiment, finely ground granulated blast furnace slag was used. This slag has latent hydraulic properties and has a surface area of $400 \mathrm{~m}^{2} / \mathrm{kg}$. The percentages of individual oxides obtained by a fluorescence spectrometer measurement are shown in Table 1. Mineralogical composition of BFS in Figure 2 shows that mainly minerals Akermanite, Merwinite and Calcite are present in this slag. The X-ray diffraction curve in Figure 2 shows that the slag is highly reactive because of a high proportion of amorphous phase [35].

\subsubsection{Cement By-Pass Dust (Cbpd)}

By-pass cement dust from the Horné Srnie cement plant was utilized in the experiment. The percentages of individual oxides obtained by a fluorescence spectrometer measurement are shown in Table 1 . The chlorine content in CBPD is $10.49 \%$. The phase composition of CBPD is given in Table 2. The LOI is $21.9 \%$ for CBPD. LOI is caused by the release of Sylvite, which begins to release at $700{ }^{\circ} \mathrm{C}$ and ends at $1100{ }^{\circ} \mathrm{C}$. Another significant weight loss is caused by the decomposition of potassium sulfate, beginning at $1100^{\circ} \mathrm{C}$. LOI is also caused 
by the dehydroxylation of portlandite and the decomposition of limestone. The chemical and phase composition of CBPD is taken from the report "Deliverable D1.1 Results from raw materials analyses" within the GeoDust project. The evaluation of the measurements was carried out using the software HighScore, version 4.0 (Malvern, Worcestershire, UK).

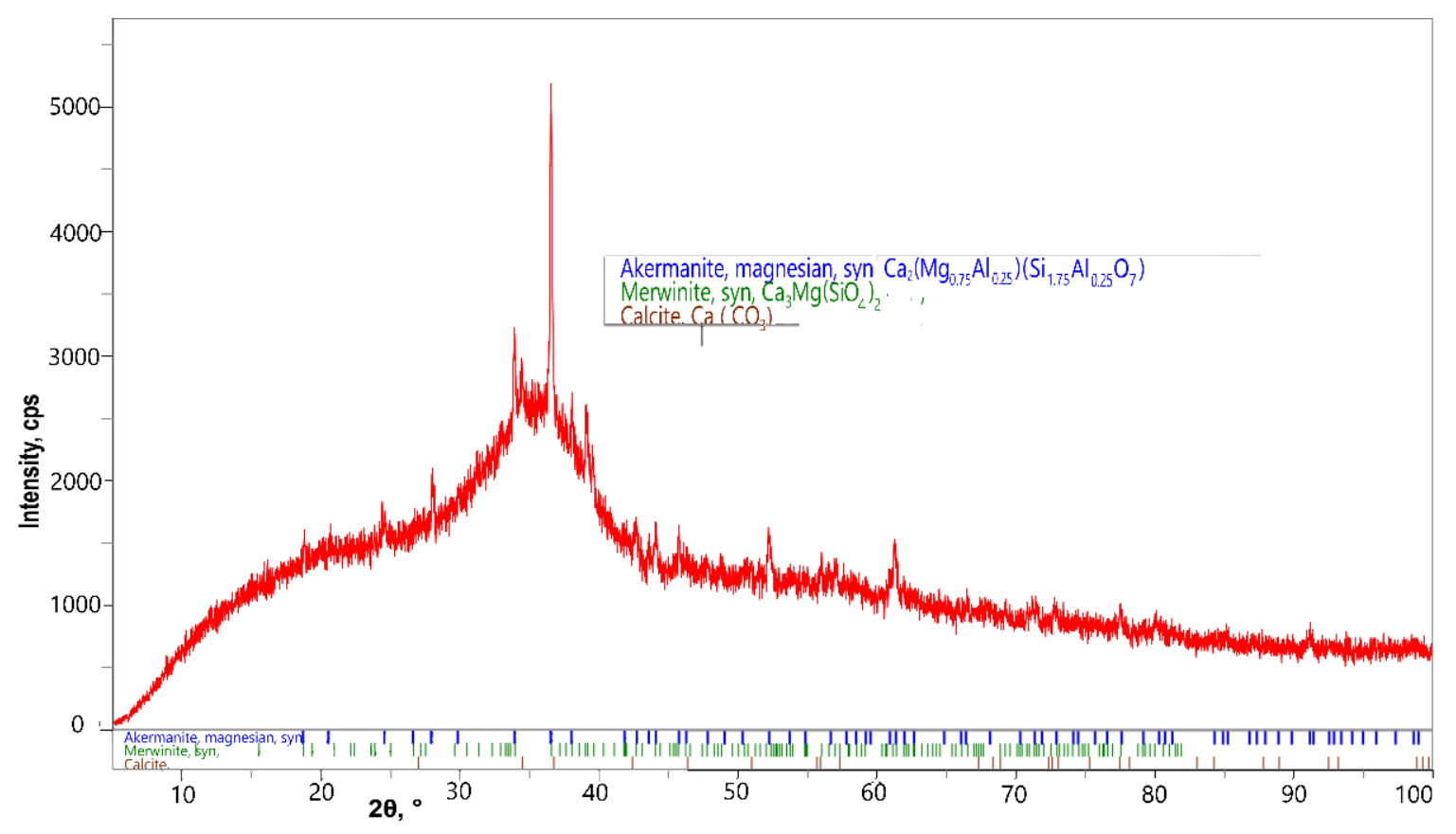

Figure 2. Mineralogical composition of BFS determined by X-ray diffraction (XRD).

Table 2. Cement by-pass dust composition (in wt. \%) measured by XRD.

\begin{tabular}{cc}
\hline Participant & Content [\%] \\
\hline Sylvite & 21.9 \\
Free CaO & 22.4 \\
Portlandite & 15.0 \\
Arcanite & 14.4 \\
Quartz & 4.02 \\
Larnite/Belite & 19.2 \\
Calcite & 1.36 \\
Dolomite & 1.67 \\
\hline
\end{tabular}

The presence of heavy metals was also monitored to determine the composition of CBPD. Zinc (1753 mg $/ \mathrm{kg})$, Lead $(785 \mathrm{mg} / \mathrm{kg})$, Bismuth $(235 \mathrm{mg} / \mathrm{kg})$, Copper $(168 \mathrm{mg} / \mathrm{kg})$, Barium (165 mg/kg), Chromium (121 mg/ $\mathrm{kg}$ ) and Cadmium $(36 \mathrm{mg} / \mathrm{kg})$ were detected by ICP-OES method. The occurrence of these metals in the material is generally risky, especially from a health point of view. However, alkali-activated materials can bind heavy metals in their structure over a long period of time, which means that the processing of these bulk materials in these composites is more than desirable. The leachability of heavy metals out of mortars in our experiment has not yet been determined, but it is assumed in the long-term schedule.

\subsubsection{Activator-Anhydrous Disodium Metasilicate (A)}

Anhydrous disodium metasilicate is a white crystalline material that contains min. $44 \% \mathrm{SiO}_{2}$. Anhydrous disodium metasilicate (MSS) produced by Penta Chemicals was used for the purposes of the experiment. This activator has a silicate modulus of 1 . The basic chemical properties stated by the producer are given in Table 3. $\mathrm{pH} 12.5$ was reached when dissolving $10 \mathrm{~g} / \mathrm{L}$ at $20^{\circ} \mathrm{C}$; this value is stated by the producer [36]. 
Table 3. Composition of anhydrous disodium metasilicate [34].

\begin{tabular}{ccc}
\hline $\mathbf{A}$ & MJ & Value \\
\hline $\mathrm{SiO}_{2}$ content & $\%$ & $\mathrm{~min} .44$ \\
$\mathrm{pH}$ & - & 12.5 \\
Molar weight & $\mathrm{kg} / \mathrm{mol}$ & 122.06 \\
Relative density & $\mathrm{g} / \mathrm{cm}^{3}$ & 2.6 \\
\hline
\end{tabular}

\subsubsection{Standardized Sand}

Standard sand CEN, ČSN EN 196-1 was used as filler in the experiment. It is natural quartz sand, which is formed by rounded particles and the silica content is $\min .98 \%$, $0 / 2 \mathrm{~mm}$ fraction and less than $0.2 \%$ moisture content [37].

\subsection{Mixtures}

As a reference mixture, previously verified mixtures tested in the previous works [38-41] were used in the experimental part. The basic mixture was derived from initial experiments, where the strength properties were monitored with different replacement of BFS with fly ash and CBPD with the possibility of using different activators. Two activators were compared (anhydrous disodium metasilicate and sodium water glass with silicate modulus of 2). Better results were obtained with the anhydrous disodium metasilicate activator; therefore, this activator was chosen for the next phase of the experiment.

For REC 1, the amount of activator is calculated from the total binder amount. For REC 2 , the dose was reduced by $15 \%$ and for REC 3, the dose was reduced by $30 \%$ and was calculated only for blast furnace slag. The reception of the raw material values is shown in Table 4. In these mixtures, a plasticizer was not used. The $\mathrm{pH}$ of the solution prepared by dissolving anhydrous disodium metasilicate in water ranged from 13.95 to 14.00 for all monitored mixtures.

Table 4. Reception of the raw material values is given in [g].

\begin{tabular}{ccccccc}
\hline Mixture & BFS & FA & CBPD & A & W & Sand \\
\hline REC 1 & 315 & 67.5 & 67.5 & 89 & 215 & 1350 \\
REC 2 & 315 & 67.5 & 67.5 & 75.65 & 215 & 1350 \\
REC 3 & 315 & 67.5 & 67.5 & 62.3 & 215 & 1350 \\
\hline
\end{tabular}

\subsection{Methods}

The aim of the research is to verify if using CBPD, as a part of a binder in the production of curbs, allows for the production of a quality product usable in practice. The results will be evaluated according to Czech standard ČSN EN 1340 (723040) [42] for concrete curbs.

Product of garden architecture-curb containing CBPD material will be applicable as an element for garden architecture, in spite of it being a product made of materials currently not used (waste). An illustrative image of an element of garden architecture is shown in Figure 3.

The potentially positive effects of the relationship between plants and alkali-activated products - pots for cultivation were discussed in [43].

Since the garden architecture elements are mostly in direct interaction with the soil, we wanted to show that these elements (alkali-activated products containing CBPD) do not have a significant negative effect on the plants in the surroundings. The following basic procedures were used to confirm or refute this idea.

Mixtures and beams were prepared (for a description of the production, see Section 2.5). Parts of the beams were analyzed in the laboratory (for a description of the methods used for the analysis, see Sections 2.6-2.9). Part of the beams were placed in situ in preprepared boxes with substrate (for a description of the procedure, see Section 2.4). 


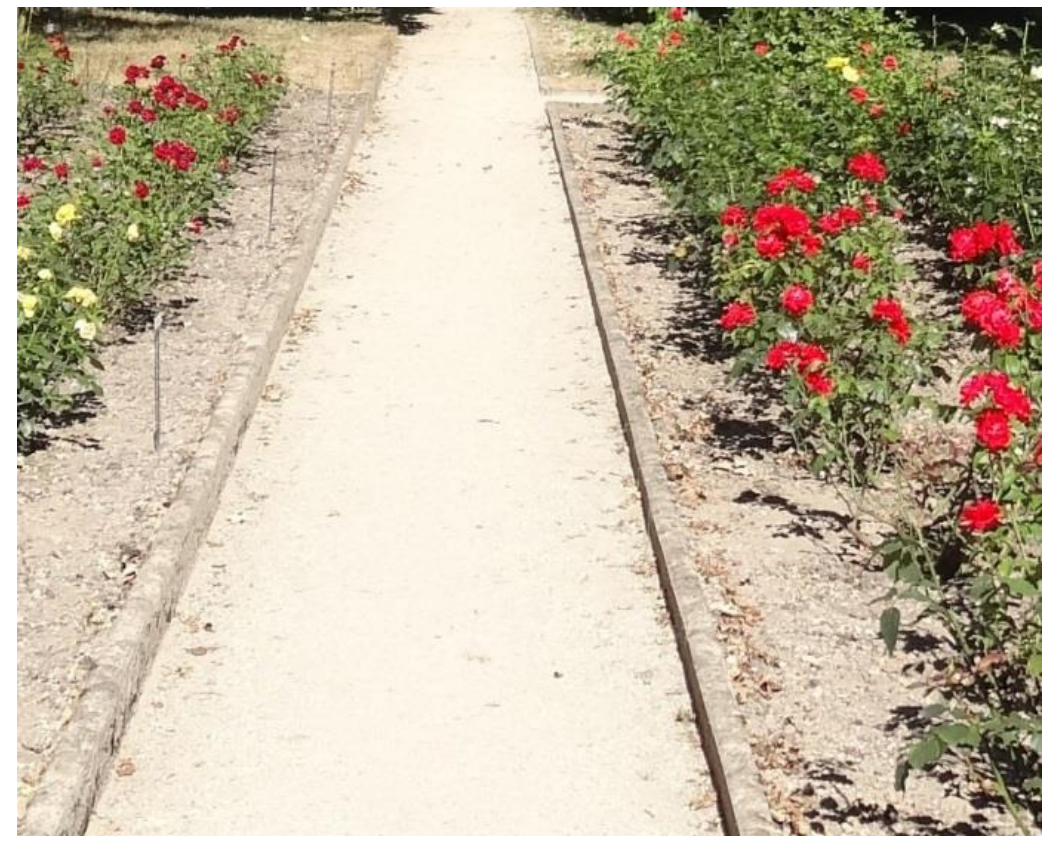

Figure 3. An element of garden architecture (B. Vojvodikova).

Curbs and other elements such as tiles are produced in operation by a vibro-pressing system. This technological procedure was not applied. It was primarily a matter of verifying the behavior of the binder component; therefore, a production process was chosen corresponding to the preparation of beams for determining the strength of cement. These elements were prepared for standard tests and for in situ testing by embedding in the soil substrate of various properties.

\subsection{Preparation of Boxes with Soil Substrate and Placement of Beams}

Four series of boxes were prepared. All boxes were filled with substrate and grass seed was always sown in them 20 days before placing the beams. A low nutrient substrate was used for the experiment. The boxes were drainless and placed in situ in a shady place. They were watered with accumulated rainwater until the beams were placed in them. Later boxes were watered only by natural rain.

To verify the impact on the environment (possible influence on plant growth) and to verify possible qualitative changes of beams (curbs) during in situ placement, boxes with a substrate for the placement of test specimens were prepared.

The experiment investigated whether the condition of the grass changes depending on the length of the placement of the beams and, furthermore, whether there is a relationship between the effects on the condition of the grassland and the length and method of treatment of the beams before they are placed in the box. In particular, attention was paid to signs of excessive or unexpected grass death, excessive yellowing outside the vegetation cycle or other signs that the grass is not thriving. These were mainly possible manifestations of a negative effect.

The experiment was launched in May.

The experiment was divided into four time sections-four series:

Series 1 -short-term period with connection to spring warm stable weather, good germination of grass seeds.

Series 2-the period included both the summer months and the winter months to observe the weather effects.

Series 3 - the period included a period of one year to be able to observe the grass during the growing season and during the dormant period.

Series 4-the period included the spring period and the summer months in the main vegetation period. 


\subsubsection{Beams-Series 1}

Beams matured in a humidity cabinet for two days, then some were placed in boxes with substrate and grass for 28 days (June) (Figure 4) and the others remained in the humidity cabinet.

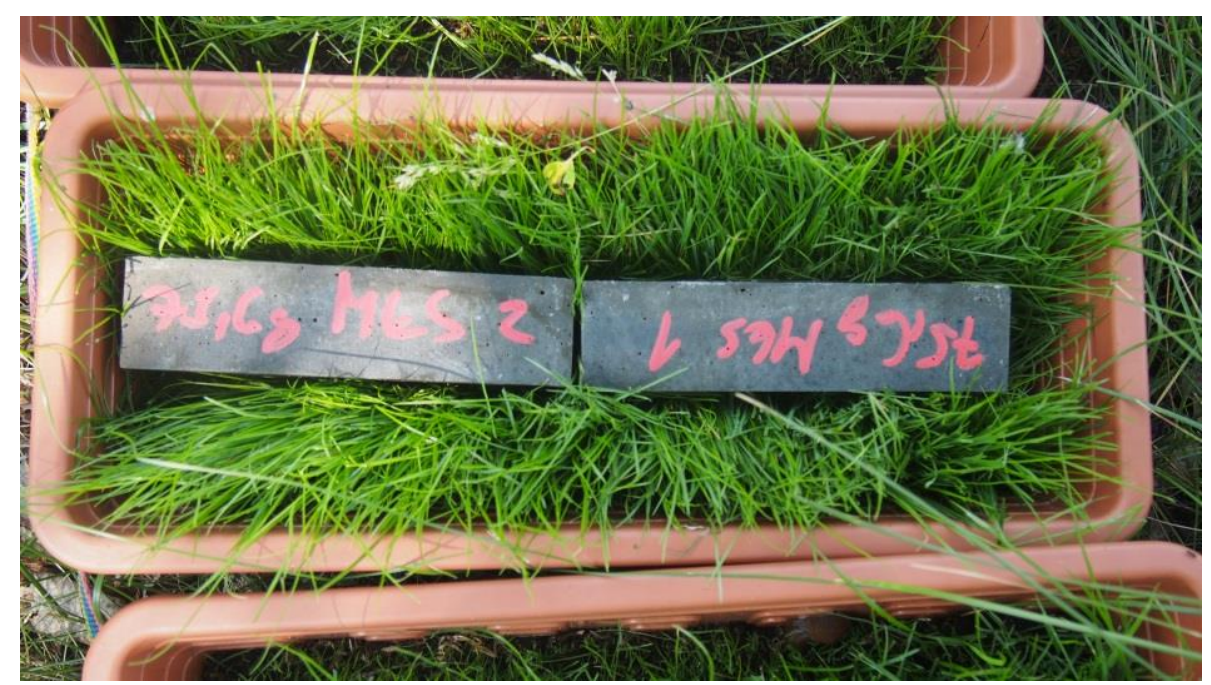

Figure 4. Placement of beams in grass boxes (B. Vojvodikova).

Beams from both boxes and the humidity cabinet were subsequently tested and the results are shown in Table 5 and graphically demonstrated in Figures 5 and 6.

Table 5. Results of basic physical and mechanical properties for Series 1.

\begin{tabular}{ccccc}
\hline \multicolumn{5}{c}{ Series 1 } \\
\hline Mixture & Placement & Compressive Strength [MPa] & Flexural Strength [MPa] & Bulk Density [kg/m ${ }^{\mathbf{3}}$ ] \\
\hline \multirow{2}{*}{ REC 1 } & Humidity cabinet & 61.2 & 6.0 & 2270 \\
& Exterior & 66.0 & 4.6 & 2230 \\
REC 2 & Humidity cabinet & 63.8 & 6.0 & 2260 \\
& Exterior & 70.5 & 4.7 & 2220 \\
REC 3 & Humidity cabinet & 69.8 & 6.8 & 2250 \\
& Exterior & 70.7 & 5.7 & 2200 \\
\hline
\end{tabular}

\subsubsection{Beams-Series 2}

Beams matured in a humidity cabinet for 28 days, then part of the specimens were placed in boxes with substrate and grass for 210 days (August-February) and the other part remained in the humidity cabinet. Beams from both boxes and the humidity cabinet were subsequently tested and the results are shown in Table 6 and graphically demonstrated in Figures 5 and 6.

\subsubsection{Beams-Series 4}

After demolding, the specimens matured for 28 days in a water bath, then placed in boxes with substrate and grass for 180 days (March-September). Beams were tested and the results are shown in Table 8 and graphically demonstrated in Figures 5 and 6.

\subsubsection{Beams-Series 3}

Beams matured for two days in a humidity cabinet, then part of the samples were placed in boxes with substrate and grass for 360 days (September-September) and the other part remained wrapped in shrink film indoors. Both types of beams were subsequently tested, and the results are shown in Table 7 and graphically demonstrated in Figures 5 and 6. 


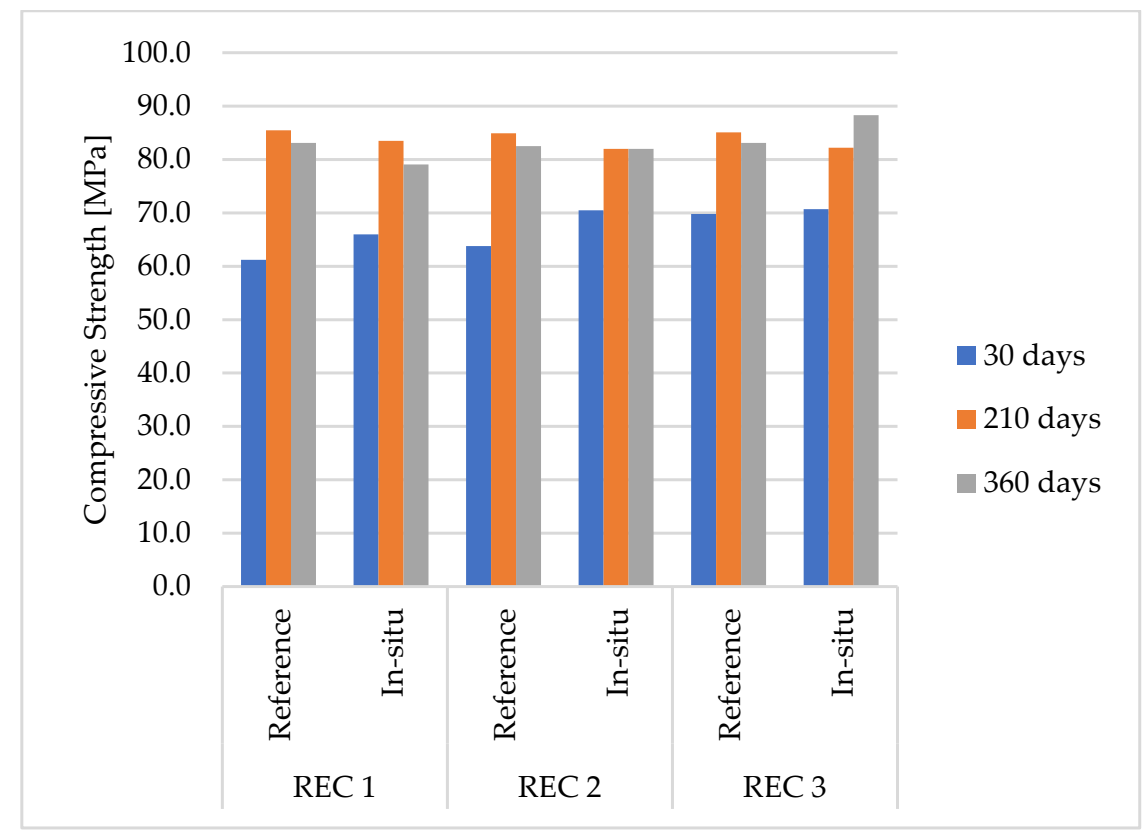

Figure 5. Compressive strength of mixtures.

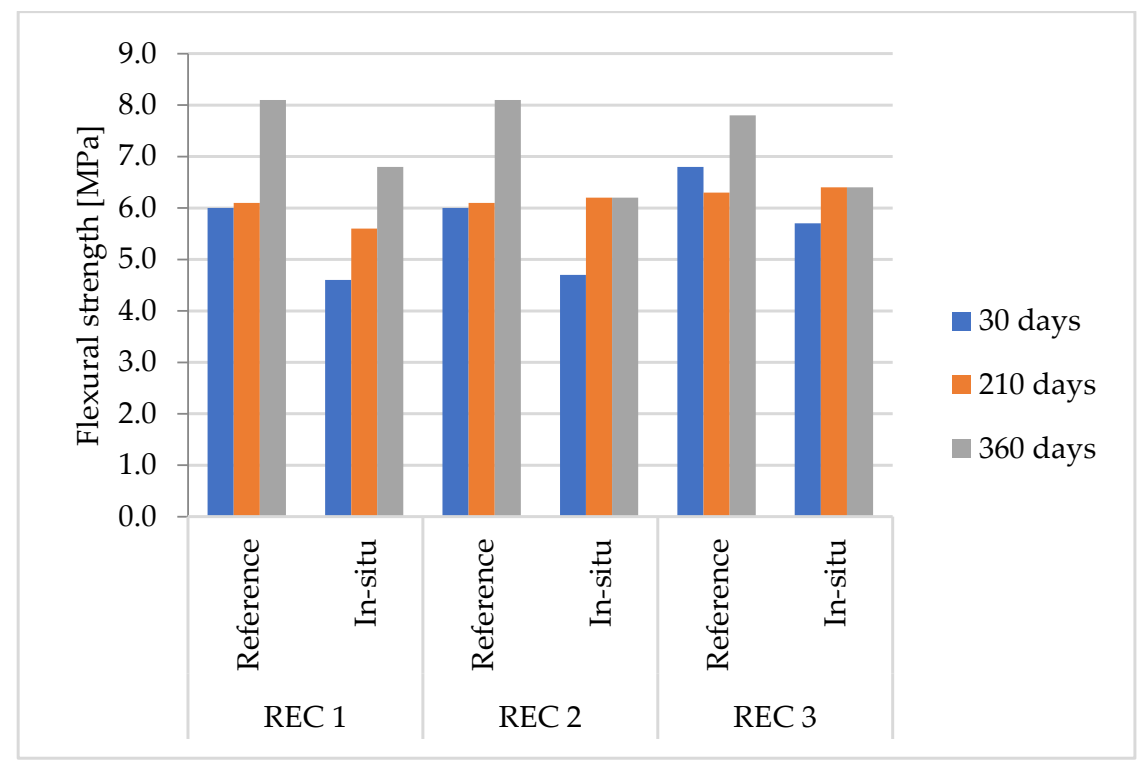

Figure 6. Flexural strength of mixtures.

Table 6. Results of basic physical and mechanical properties for Series 2.

\begin{tabular}{ccccc}
\hline \multicolumn{4}{c}{ Series 2 } \\
\hline Mixture & Placement & Compressive Strength [MPa] & Flexural Strength [MPa] & Bulk Density [kg/m ${ }^{\mathbf{3}}$ ] \\
\hline \multirow{2}{*}{ REC 1 } & Humidity cabinet & 85.5 & 6.1 & 2250 \\
& Exterior & 83.5 & 5.6 & 2270 \\
REC 2 & Humidity cabinet & 84.9 & 6.1 & 2250 \\
& Exterior & 82.0 & 6.2 & 2260 \\
REC 3 & Humidity cabinet & 85.1 & 6.3 & 2270 \\
& Exterior & 82.2 & 6.4 & 2260 \\
\hline
\end{tabular}


Table 7. Results of basic physical and mechanical properties for Series 3.

\begin{tabular}{ccccc}
\hline \multicolumn{3}{c}{ Series 3 } \\
\hline Mixture & Placement & Compressive Strength [MPa] & Flexural Strength [MPa] & Bulk Density [kg/m ${ }^{3}$ ] \\
\hline \multirow{2}{*}{ REC 1} & Interior & 83.1 & 8.1 & 2260 \\
& Exterior & 79.1 & 6.8 & 2270 \\
REC 2 & Interior & 82.5 & 8.1 & 2250 \\
& Exterior & 82.0 & 6.2 & 2270 \\
REC 3 & Interior & 83.1 & 7.8 & 2270 \\
& Exterior & 88.3 & 6.4 & 2240 \\
\hline
\end{tabular}

Table 8. Results of basic physical and mechanical properties for Series 4 .

\begin{tabular}{ccccc}
\hline \multicolumn{5}{c}{ Series 4 } \\
\hline Mixture & Placement & Compressive Strength [MPa] & Flexural Strength [MPa] & Bulk Density [kg/m ${ }^{3}$ ] \\
\hline REC 1 & Exterior & 89.3 & 8.7 & 2280 \\
REC 2 & Exterior & 99.8 & 7.1 & 2250 \\
REC 3 & Exterior & 99.9 & 7.5 & 2270 \\
\hline
\end{tabular}

As part of the analysis, changes of the $\mathrm{pH}$ of the substrate from the box were measured, found changes in the grassland were observed. The $\mathrm{pH}$ measurement was performed from the prepared extracts of soil taken from the space on the sides and under the beam.

The condition of the grass was checked visually and possible signs of plant inhibition were monitored. The root ball was also inspected for signs of significant damage.

\subsection{Preparation of Beams and Verification of Properties}

To verify how the binder component of the alkali-activated material based on blast furnace slag with ash admixture will behave after denitrification by the SNCR method and by-pass dust $(\mathrm{CBPD})$, specimens measuring $(40 \times 40 \times 160) \mathrm{mm}^{3}$ were prepared; the preparation of mixtures followed standard standards requirements for the preparation of mortars and cements.

To verify the qualitative properties, the following parameters were verified: strength, frost resistance, determination of resistance to chemical defrosting agents, thermal analysis and analysis of infrared spectroscopy with Fourier transformation.

All necessary raw materials were weighed into the mixture with a precision of $\pm 1 \mathrm{~g}$. First, binder components such as slag, fly ash and dust were poured into the container; activator and water were added. The mixing procedure was in accordance with the requirements of Czech standards ČSN EN 196-1 and ČSN EN 196-3. The binder component, together with the addition of activator and water, was mixed for $90 \mathrm{~s}$ at a low mixing speed according to ČSN EN 196-3. At the end of the cycle, mixing occurred according to the requirements of ČSN EN 196-1 with a total mixing time of 180 s, during which the sand was automatically dosed $[37,44]$.

\subsection{Strength}

To determine the basic strengths, the specimens were stored in a humidity cabinet until testing. To determine the frost resistance and resistance to chemical defrosting agents, the elements were placed in a water bath after demolding.

The strengths were determined with a hydraulic press. The determination of the flexural strength was carried out by uniform loading at speeds of $(50 \pm 10) \mathrm{N} / \mathrm{s}$. The compressive strength was determined by uniform loading at a rate of $(2400 \pm 200) \mathrm{N} / \mathrm{s}$ [37].

\subsection{Frost Resistance}

The determination of frost resistance occurred in a freezer with automatic cycling according to ČSN 722452. Cycling temperatures in the frost area were in the range of -15 to $-20{ }^{\circ} \mathrm{C}$; a water bath with a water temperature of $20^{\circ} \mathrm{C}$ was used for thawing. One cycle consists of $4 \mathrm{~h}$ of freezing and $2 \mathrm{~h}$ of thawing [45]. 


\subsection{Scaling Resistance}

The determination of resistance to the action of deicing chemicals was also performed on elements measuring $40 \times 40 \times 160 \mathrm{~mm}^{3}$ according to the concrete standard ČSN 731326 in a freezer with automatic cycling. The test was performed according to the method A of the relevant standard. The cycling temperatures were $-15^{\circ} \mathrm{C}$ for $15 \mathrm{~min}$ and $+20^{\circ} \mathrm{C}$ again for $15 \mathrm{~min}$. The specimens are placed into the freezer in the appropriate dishes into which the $3 \%$ sodium chloride solution is poured so that the specimen is immersed $5 \pm 1 \mathrm{~mm}$. After each 25 cycles, the loosened parts are drained off the dishes and they are dried at $105^{\circ} \mathrm{C}$ and the mass waste is weighed [46].

\subsection{Analytical Methods}

Parts were cut from the selected specimens and thermal analysis and analysis of infrared spectroscopy with Fourier transformation were subsequently performed.

Thermal analyses was performed on an SDT Q600 from TA Instrument with a heating rate of $10^{\circ} \mathrm{C} / \mathrm{min}$ to $1000{ }^{\circ} \mathrm{C}$ with a 2 min hold at this temperature. The evaluation was performed by TA Instruments software, Universal Analysis 2000.

Infrared spectroscopy was performed on a Nicolet iS50 FT-IR instrument. The experiment used a sample compartment iS 50 ATR, a detector DTGS ATR and a beam splitter kBr. The measurement took place in the range of $400-4000 \mathrm{~cm}^{-1}$.

X-ray diffraction was performed on a Rigaku MinyFlex instrument in the range of $5-100^{\circ} 2$ theta at a speed of $3^{\circ} / \mathrm{min}$. The $\mathrm{D} /$ tex Ultra 2 detector was used in the measurement and the $15 \mathrm{~mA}$ lamp voltage was $40 \mathrm{kV}$.

Infrared spectroscopy and X-ray diffraction were determined on pastes with no sand. The ratio between the binder components and the activator remained the same according to Table 4 . Only the water content changed to a water/solid ratio of 0.42 , because for pastes it is not necessary to calculate the water for the wettability of aggregate grains. For pastes a lower water coefficient is used than for mortars and concretes.

In Series 3 (see Section 2.4.4), 3-4 mm plates of the surface layer were cut from the specimens to perform analytical methods. These plates were crushed and ground to a fine powder and subsequently tested by thermal analysis and infrared spectroscopy with Fourier transform. The results of infrared spectroscopy are described only verbally without a graphic output. This testing was realized on filler of tested beams including sand, so it cannot be quite clearly determined the bonds corresponding to the hydration products and bonds corresponding to the quartz sand. This measurement was mainly focused on the change of state between samples from the interior and exterior and on the identification of degradation products

\section{Results and Discussion}

\subsection{Determination of Basic Physical-Mechanical Properties}

One of the first results was the determination of basic physical-mechanical properties for the Series 1 of beams. This evaluation was necessary to verify the basic properties of CBPD as part of the binder in the mixture. The results are shown in Table 9.

Achieved results of basic physical and mechanical properties show that by-pass dust particles mainly contribute to a rapid increase of strength, especially flexural strength, when the mixture marked REC 1 achieved almost $92 \%$ strength after one day of maturation that was achieved after 28 days. For other mixtures, the proportion was lower, $75 \%$ for REC 2 and $66 \%$ for REC 3. For Mixture 3, where the binder component consisted only of BFS without the addition of FA and CBPD, the proportion of strength after 1 day of maturation was approximately $34 \%$, for Mixture 2 the strengths were around $40 \%$ of the 28 -day strength and for Mixture 1, it was around $45 \%$. Samples without admixtures achieved approximately $50 \%$ of values compared to 28 -day strength than mixtures with admixtures. As part of another experiment, the influence of fly ash on the properties of alkali-activated BFS-based materials was studied. With a $10 \%$ replacement of slag by fly ash after denitrification, approximately $45 \%$ strength was achieved after 2 days of maturation after 28 days. The 
increase of compressive strength was not as rapid as in the case of flexural strength. After one day of maturation mixtures reached strengths of about $40 \%$ of the 28 -day strength. We can assume that such rapid increases in strength correspond primarily to the use of by-pass dusts, since during the verification of the applicability of fly ash after denitrification by SNCR method, no accelerated setting of alkali-activated materials based on blast furnace slag was found. After 28 days of maturation, the highest strength values reached REC3, where the smallest amount of activator was added.

Table 9. Results of basic physical and mechanical properties of the prepared mixtures.

\begin{tabular}{ccccc}
\hline \multicolumn{2}{c}{ MSS } & & \\
\hline $\begin{array}{c}\text { Mixture } \\
\text { Units }\end{array}$ & $\begin{array}{c}\text { Age in Days } \\
\text { Age }\end{array}$ & $\begin{array}{c}\text { Bulk Weight } \\
{\left[\mathbf{k g} / \mathbf{m}^{3}\right]}\end{array}$ & $\begin{array}{c}\text { Compressive Strength } \\
{[\mathbf{M P a}]}\end{array}$ & $\begin{array}{c}\text { Flexural Strength } \\
{[\mathbf{M P a}]}\end{array}$ \\
\hline \multirow{2}{*}{ REC 1 } & 1 & 2250 & 26.4 & 5.5 \\
& 2 & 2250 & 33.8 & 5.6 \\
& 7 & 2250 & 45.7 & 5.6 \\
& 14 & 2260 & 49.7 & 5.6 \\
REC 2 & 28 & 2270 & 61.2 & 6.0 \\
& 1 & 2260 & 25.2 & 5.5 \\
& 2 & 2250 & 34.8 & 5.7 \\
& 7 & 2230 & 43.4 & 5.7 \\
REC 3 & 14 & 52.3 & 5.7 \\
& 28 & 2260 & 63.8 & 6.0 \\
& 1 & 2210 & 27.3 & 4.5 \\
& 2 & 2210 & 38.3 & 5.8 \\
\end{tabular}

\subsection{Frost Resistance}

The specimens were stored in a water bath for 28 days, then placed in a freezer for 100 cycles. The reference series remained in the water bath until testing. The results are shown in Table 10.

Table 10. Results of mixtures properties after 100 cycles of frost resistance.

\begin{tabular}{ccccccc}
\hline & $\begin{array}{c}\text { Compressive } \\
\text { Strength Ref } \\
\text { [MPa] }\end{array}$ & $\begin{array}{c}\text { Compressive } \\
\text { Strength Frost } \\
\text { [MPa] }\end{array}$ & $\begin{array}{c}\text { Coefficient of } \\
\text { Frost Resistance } \\
{[-]}\end{array}$ & $\begin{array}{c}\text { Flexural } \\
\text { Strength Ref } \\
\text { [MPa] }\end{array}$ & $\begin{array}{c}\text { Flexural } \\
\text { Strength Frost } \\
\text { [MPa] }\end{array}$ & $\begin{array}{c}\text { Coefficient of Frost } \\
\text { Resistance [-] }\end{array}$ \\
\hline REC 1 & 74.7 & 76.9 & 1.03 & 5.6 & 5.9 & 1.05 \\
REC 2 & 78.2 & 79.1 & 1.01 & 5.8 & 5.9 & 1.02 \\
REC 3 & 80.1 & 84.5 & 1.05 & 5.9 & 6.0 & 1.02 \\
\hline
\end{tabular}

No decreases in strength compared to the reference series were observed during the frost resistance testing. On the contrary, there were some slight increases in strengths. Authors in [47] report a decrease in compressive strength of only $6 \%$ after 300 cycles for alkali-activated blast furnace granulated slag.

\subsection{Scaling Resistance}

The results of the scaling resistance test are shown in Table 11.

Table 11. Conversion of weight loss per area after each 25 cycles of scaling resistance.

\begin{tabular}{ccccccccc}
\hline Mixture & Cycles & $\mathbf{0}$ & $\mathbf{2 5}$ & $\mathbf{5 0}$ & $\mathbf{7 5}$ & $\mathbf{1 0 0}$ & $\mathbf{1 2 5}$ & $\mathbf{1 5 0}$ \\
\hline REC 1 & $\rho_{\mathrm{a}}\left[\mathrm{g} / \mathrm{m}^{2}\right]$ & 0 & 574.49 & 1371.99 & 1965.55 & 2411.57 & 3125.55 & 3753.88 \\
REC 2 & $\rho_{\mathrm{a}}\left[\mathrm{g} / \mathrm{m}^{2}\right]$ & 0 & 506.37 & 1239.67 & 1790.50 & 2301.52 & 3144.90 & 3731.29 \\
REC 3 & $\rho_{\mathrm{a}}\left[\mathrm{g} / \mathrm{m}^{2}\right]$ & 0 & 457.43 & 992.24 & 1475.04 & 2008.99 & 2618.20 & 3153.85 \\
\hline
\end{tabular}


The scaling resistance results do not meet the requirements for curbs used for roads where encounters with deicing chemicals are expected. However, mixtures are tested for garden architecture in order to be used in parks, so encounters with these deicing substances are not expected. The ČSN EN 1340 [42] standard states that the weight waste for road and pedestrian roads after 100 cycles of the method A is wasted up to $1000 \mathrm{~g} / \mathrm{m}^{2}$. This requirement has not been met in any mixture. For REC 3, which worked the best, the waste weight of up to $1000 \mathrm{~g} / \mathrm{m}^{2}$ was met at 50 cycles. As the use is not intended in places where the use of road salts will occur, this negative result should not affect the possible use in garden facilities.

Worse scaling resistance of ordinary Portland cement-based materials to a partial substitution of Portland cement with fly ash is well known [48]. Moreover, the scaling resistance of AAM is also mentioned [49]. In comparison with OPC based materials, AAMs show a different microstructure. The pore solution of Portland cement system is rich in $\mathrm{Ca}$, while the pore solution of AAM is rich in sodium and silicon. The deicing solution of $\mathrm{NaCl}$ can reduce the alkalinity of the pore solution and it can destabilize the hydrates in the matrix of AAM. This can affect the poor scaling resistance of AAM. The damaging effect of $\mathrm{Cl}^{-}$is also reported in [50]. Some increase in the scaling resistance of AAM was achieved by applying air entraining and adding some organic additives [49].

\subsection{Results of In Situ Tests}

The determination of the basic physical-mechanical properties for the in situ tests and the reference comparison series are shown in Tables 5-8 and graphically demonstrated in Figures 5 and 6.

No marked changes in the observed properties were noticed in the monitoring of basic physical and mechanical properties in in situ samples or in the subsequent comparison with the reference series. In terms of flexural strength, Series 3 is particularly interesting when the reference series was not placed in a humidity box but was wrapped in a shrink film, which ensured that the specimens would not dry out. For this series, the flexural strength of REC 1 was $2 \mathrm{MPa}$ higher than in the previous series. It is unlikely that there will be such a large increase in strength between 210 and 360 days, which is the difference between Series 2 and Series 3. It is more likely that the difference in flexural strength is caused by the method of storing the specimens, when Series 2 was deposited in a humidity cabinet with stable temperature and high humidity, while Series 3 was only wrapped in shrink wrap which prevented material from drying out. An interesting question arises from these results as to which environment is more suitable for the hydration of alkali-activated materials; whether stable temperature and high humidity (98\%) or if it is just enough to stop the material from drying out, for example, by wrapping the specimen in a shrink film. In the case of compressive strength, the difference between the placements was almost non-existent; better results were obtained when stored in a humidity box, but the difference between the strengths was up to $2.8 \%$. The Czech standard ČN EN 1340 [40], which states the characteristic flexural strength of $6 \mathrm{MPa}$ for the highest class of curbs. With one-year in situ storage for Series 3, the minimum strength condition for highest class of curbs was met for all specimens. In Series 2, the characteristic strength condition was evaluated for REC 2 and REC 3. In Series 1, the characteristic strength condition was not measured for any mixture. For lower class of curbs Czech standard ČN EN 1340 states a characteristic flexural strength of $5 \mathrm{MPa}$; the conditions are met for all mixtures except REC 1 in Series 1.

\subsection{Analytical Tests}

The process of carbonation of alkali-activated materials with high amount of calcium, counting the dissolution of $\mathrm{CO}_{2}$ in the pore solution to form carbonic acid which reacts directly with the C-A-S-H gel, consequently formed $\mathrm{CaCO}_{3}$ [26].

As a part of the visual evaluation of degradation, was used a phenolphthalein solution shows an orientation transition between the layer where the $\mathrm{pH}$ dropped below 9 and the layer with $\mathrm{pH}$ above 9. The degradation occurred mainly on the three sides to which air 
had access. For the side which was in contact with the soil, there is little or no degradation. The image of the degraded layer is shown in Figure 7, when a decrease in the $\mathrm{pH}$ in the degraded surface layer was detected by means of a phenolphthalein solution.
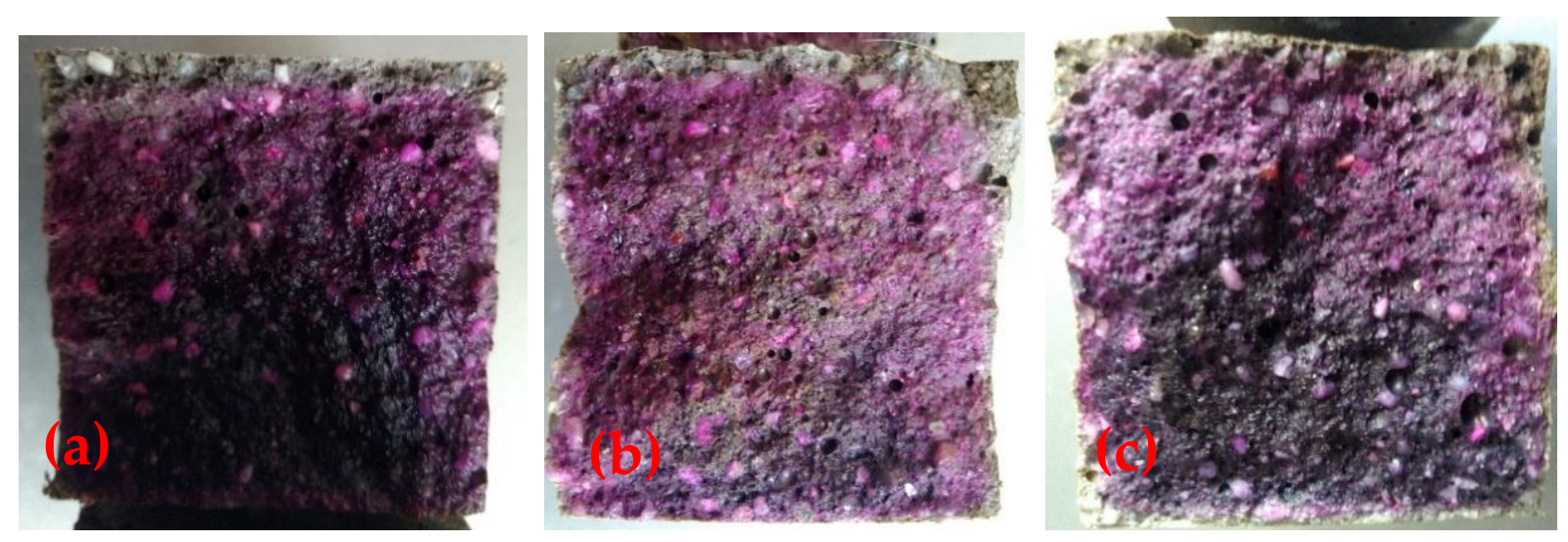

Figure 7. Visual presentation of pH decreases in the degraded layer (a) REC 1, (b) REC 2, (c) REC 3.

In Series 3, the degraded surface layer was tested when deposited in situ and was compared with the reference series by thermal analysis and FITR. See the description of the analytical method. The results of the thermal analysis are shown in Figures 8-10. The results of the FTIR analysis will be described only verbally.

FTIR results are shown in Figures 11-13 and X-ray diffraction (XRD) results are shown in Figure 14.

\subsubsection{Thermal Analysis}

Thermal analyses are used to identify components for which temperature changes or decomposition reactions are clearly visible. For example, when identifying degradation products in the material structure, we can use thermal analysis to determine the amount of degradation product formed.

Thermal analysis (Figures 8-10) was performed primarily to identify the degradation product in a sample that was stored in situ for one year. For comparison, a reference series stored in the laboratory for the same time was also tested. The storage description is described in detail in Section 2.4.4.

As part of the thermal analysis of the surface layer, the conversion of $\alpha$-quartz to $\beta$-quartz in the area of $573{ }^{\circ} \mathrm{C}$ was confirmed in all monitored specimens. These transformations are caused by the presence of quartz sand as a filler. Decomposition of limestone in the area with maxima in the range of $700-730^{\circ} \mathrm{C}$ was determined for specimens placed outdoors. The limestone content in the tested samples ranged from 2.76 to $4.32 \%$. The highest limestone content was found in REC 1 and the lowest limestone content was found in REC 2.

The weight loss curve shows a release of low-temperature water in the area of $0-200{ }^{\circ} \mathrm{C}$ and slowly releasing water in the area of $200-600^{\circ} \mathrm{C}$. In the specimens stored in situ, we can then see a slight exothermic reaction in the region of $830^{\circ} \mathrm{C}$, when the hydration product recrystallizes to pseudowollastonite [51].

The authors in [50] attribute the weight loss of alkali-activated materials in thermal analysis at temperatures above $100{ }^{\circ} \mathrm{C}$ to the dehydration of the main hydration products of the C-A-S-H (N-A-S-H) gel and the dehydroxylation of hydroxyl groups which are also present in hydration products [52].

The authors in [53] describe that water in inorganic materials such as alkali-activated materials (geopolymers) is present in several forms. It is hygroscopic (so-called free) water which is removed up to a temperature of $120^{\circ} \mathrm{C}$. Another type is strong physically bound water which is removed in the temperature range $120-300^{\circ} \mathrm{C}$. This water can be divided 
into several subgroups: crystallization water, hydrogel water and zeolitic water. When the temperature exceeds $300^{\circ} \mathrm{C}$, the chemically bound water is removed [53].

(a)

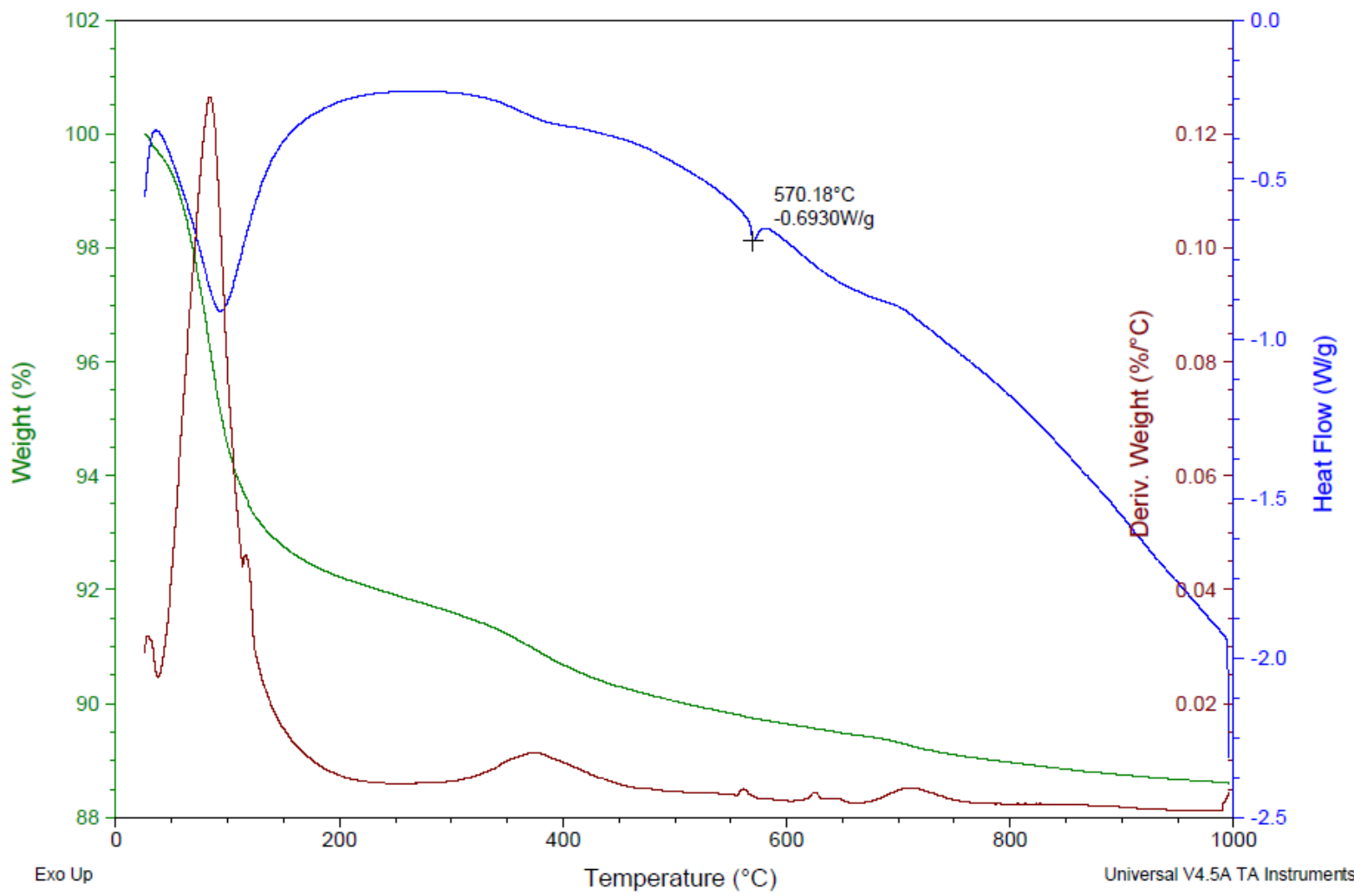

(b)

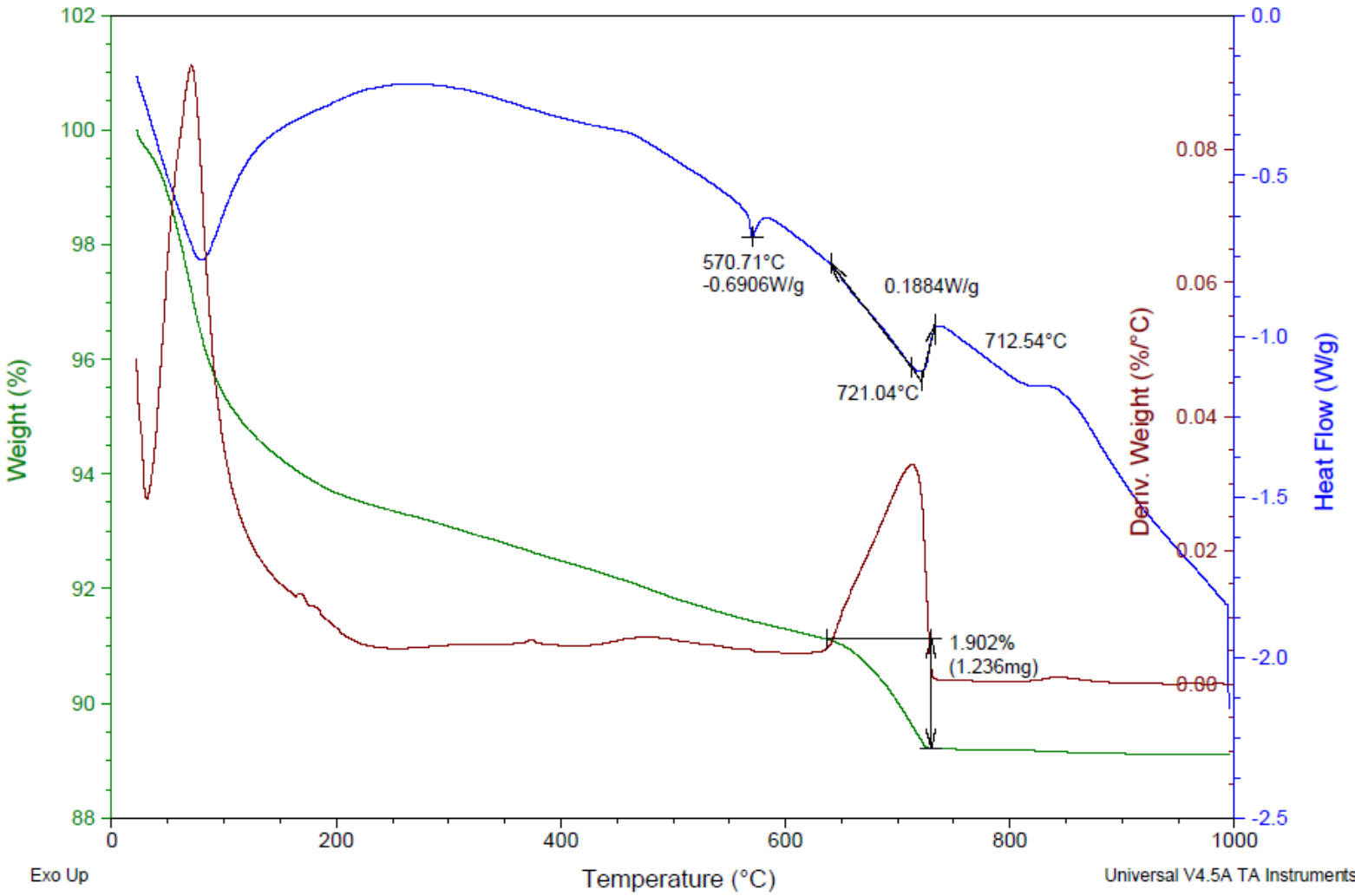

Figure 8. Thermal analysis REC 1 (a) indoor storage (b) in situ storage. 
(a)

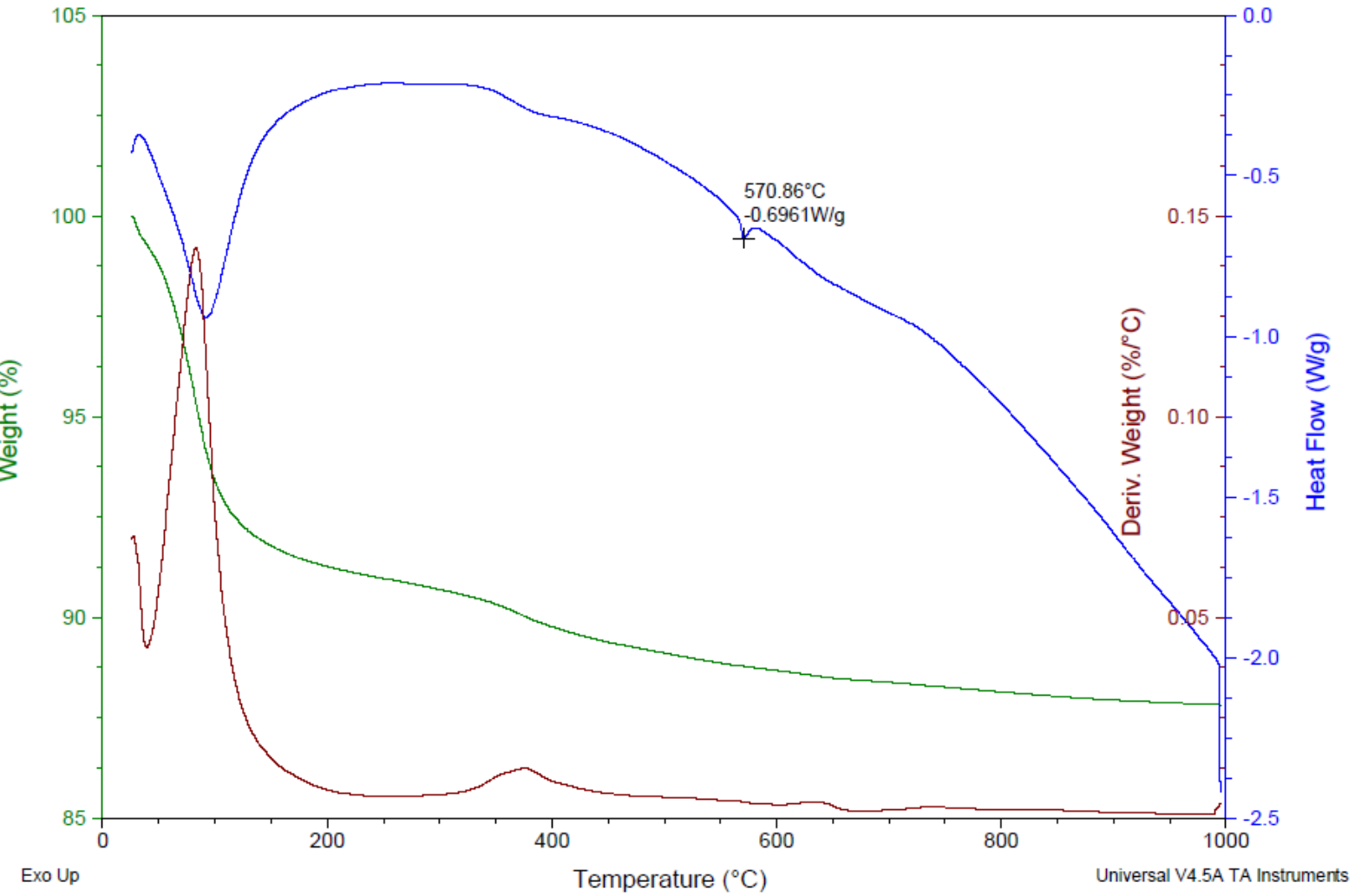

(b)

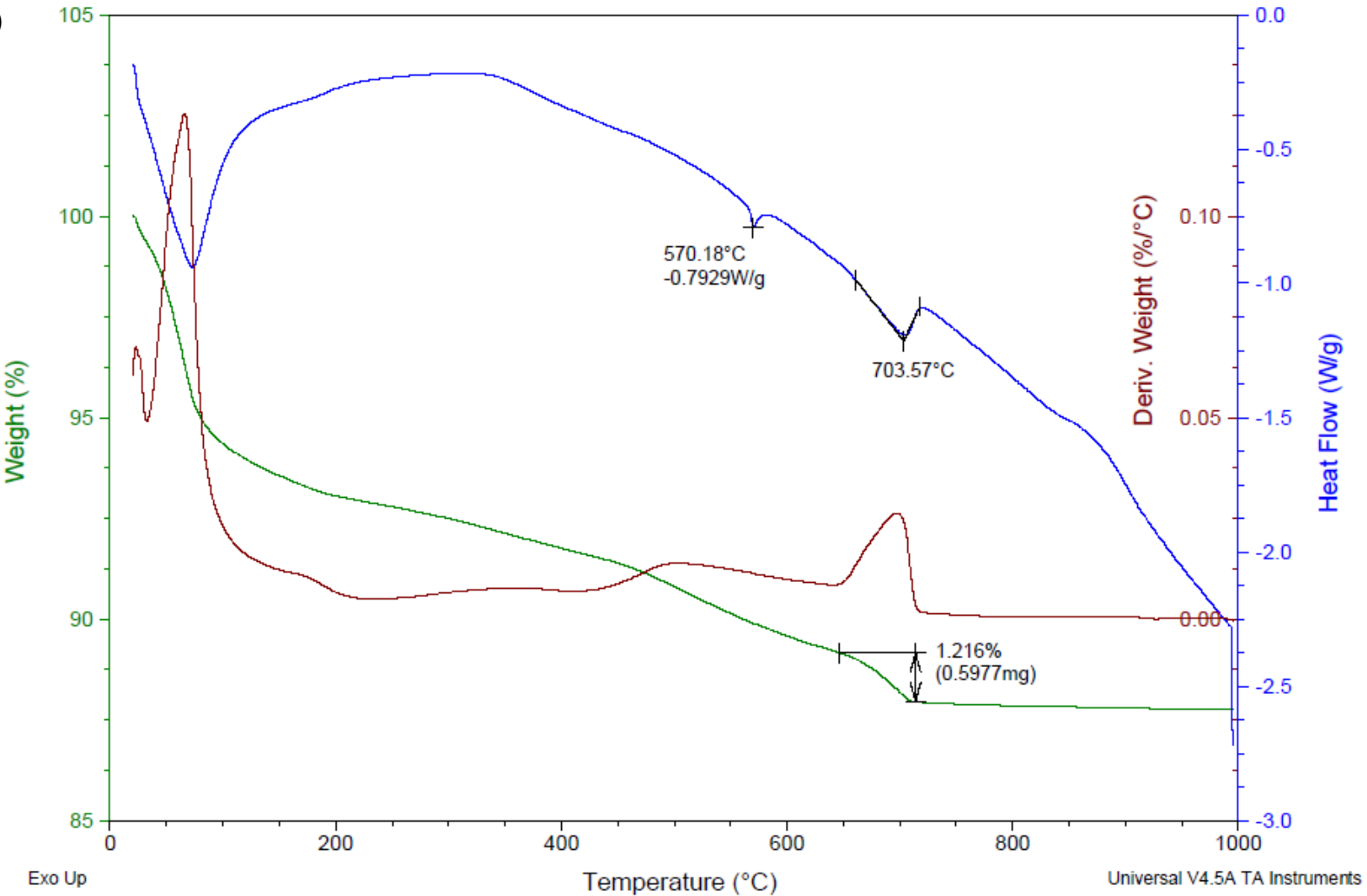

Figure 9. Thermal analysis REC 2 (a) indoor storage (b) in situ storage. 
(a)

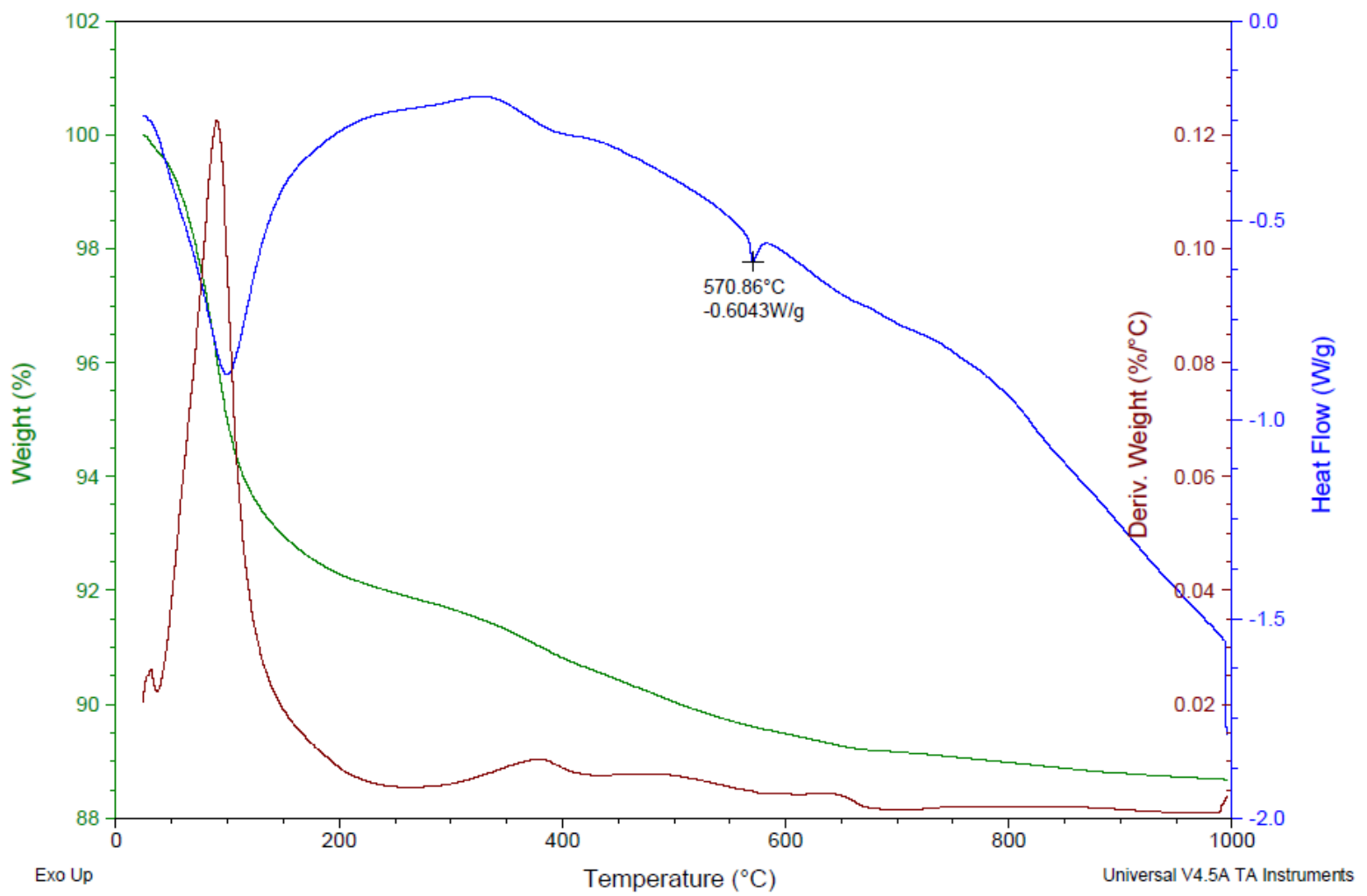

(b)

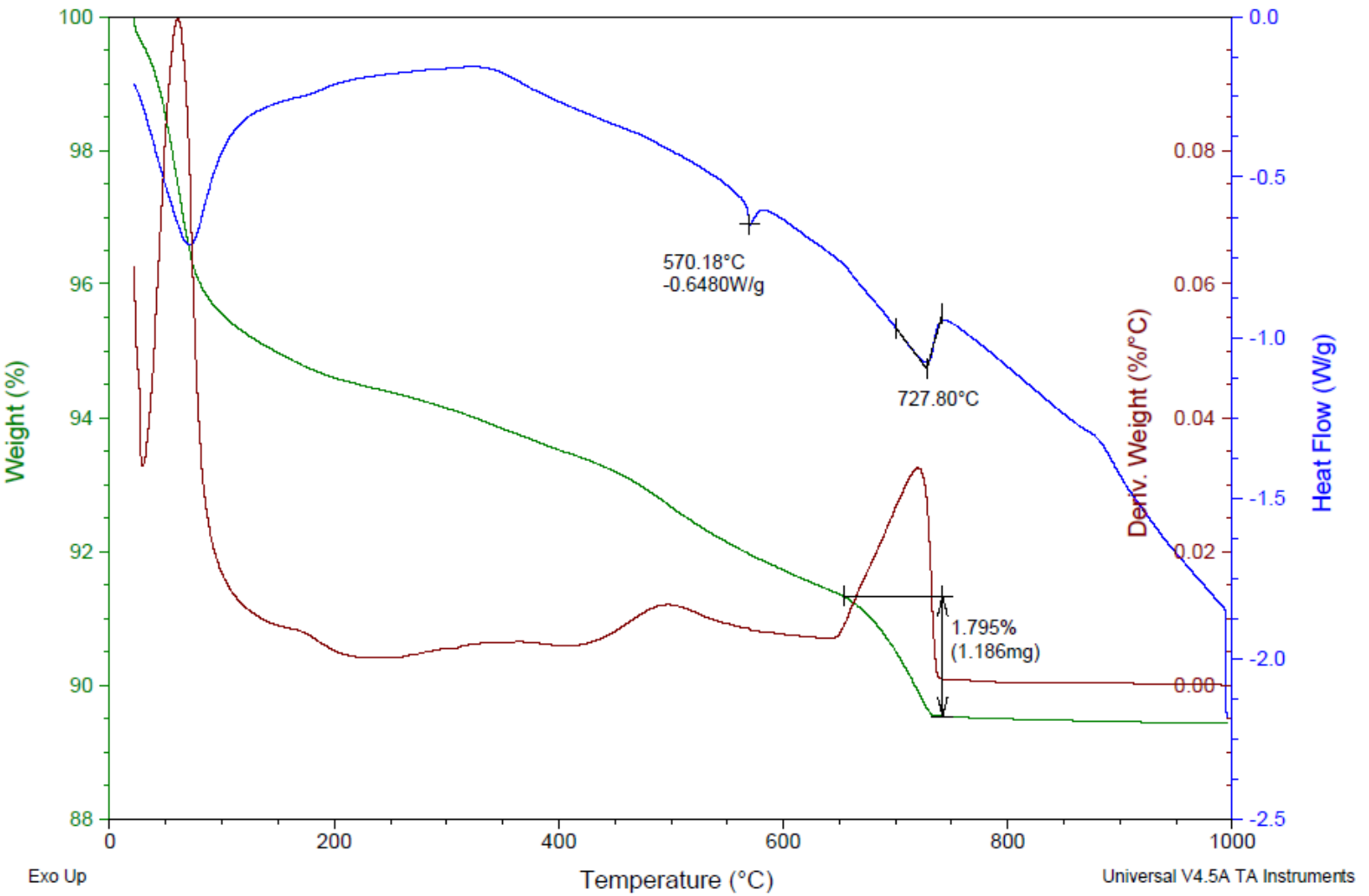

Figure 10. Thermal analysis REC 3 (a) indoor storage (b) in situ storage. 


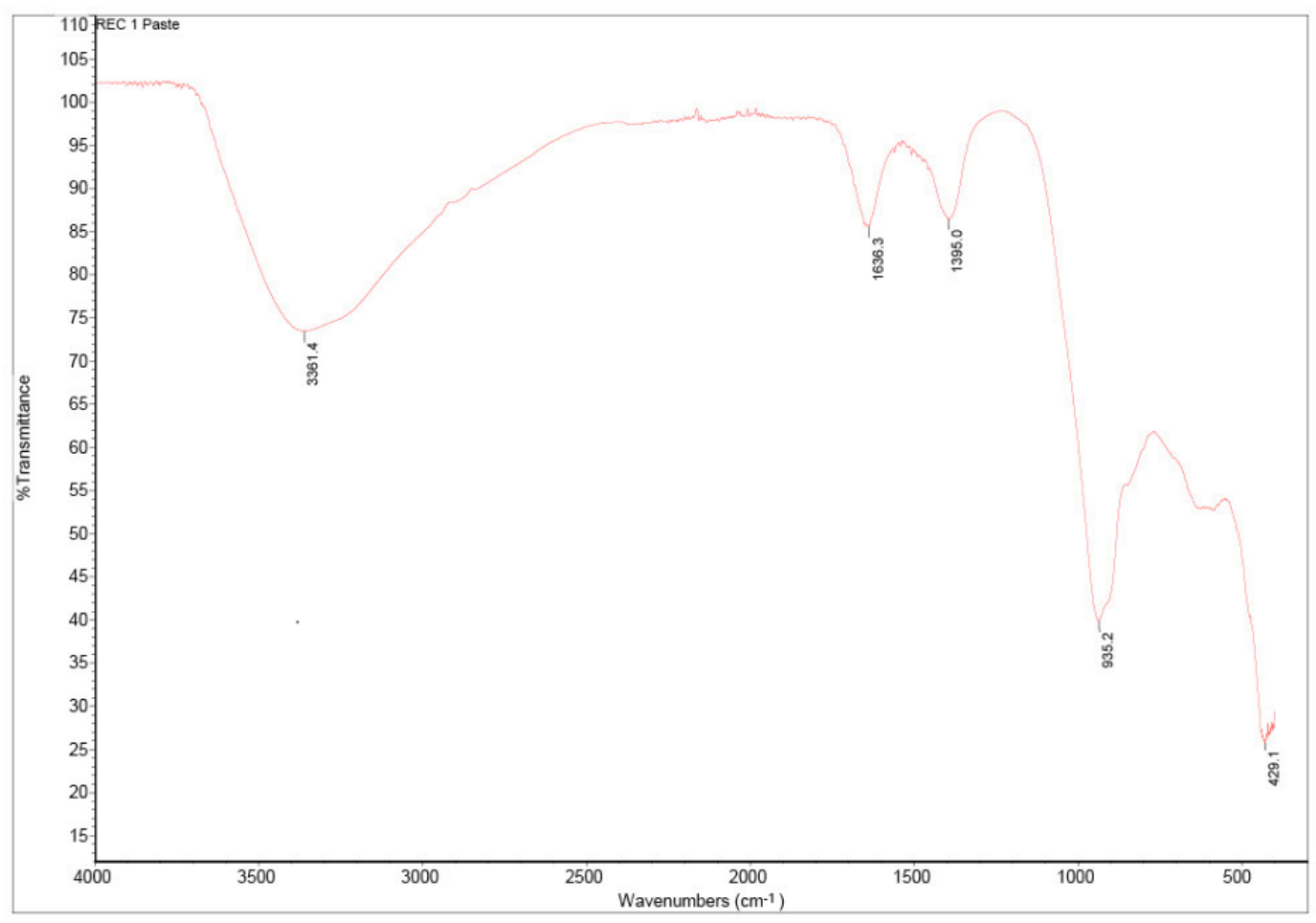

Figure 11. FTIR analysis for REC 1.

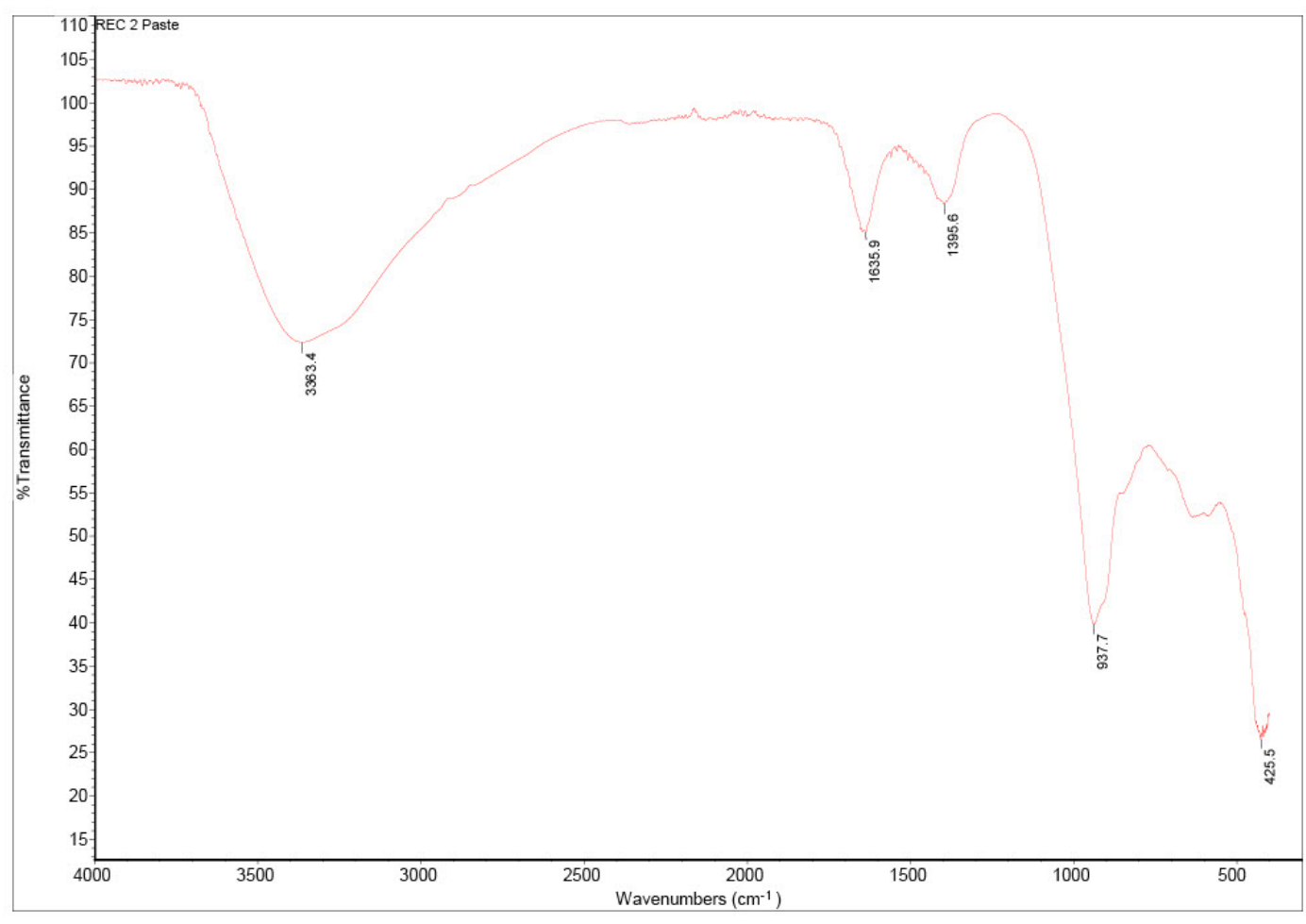

Figure 12. FTIR analysis for REC 2. 


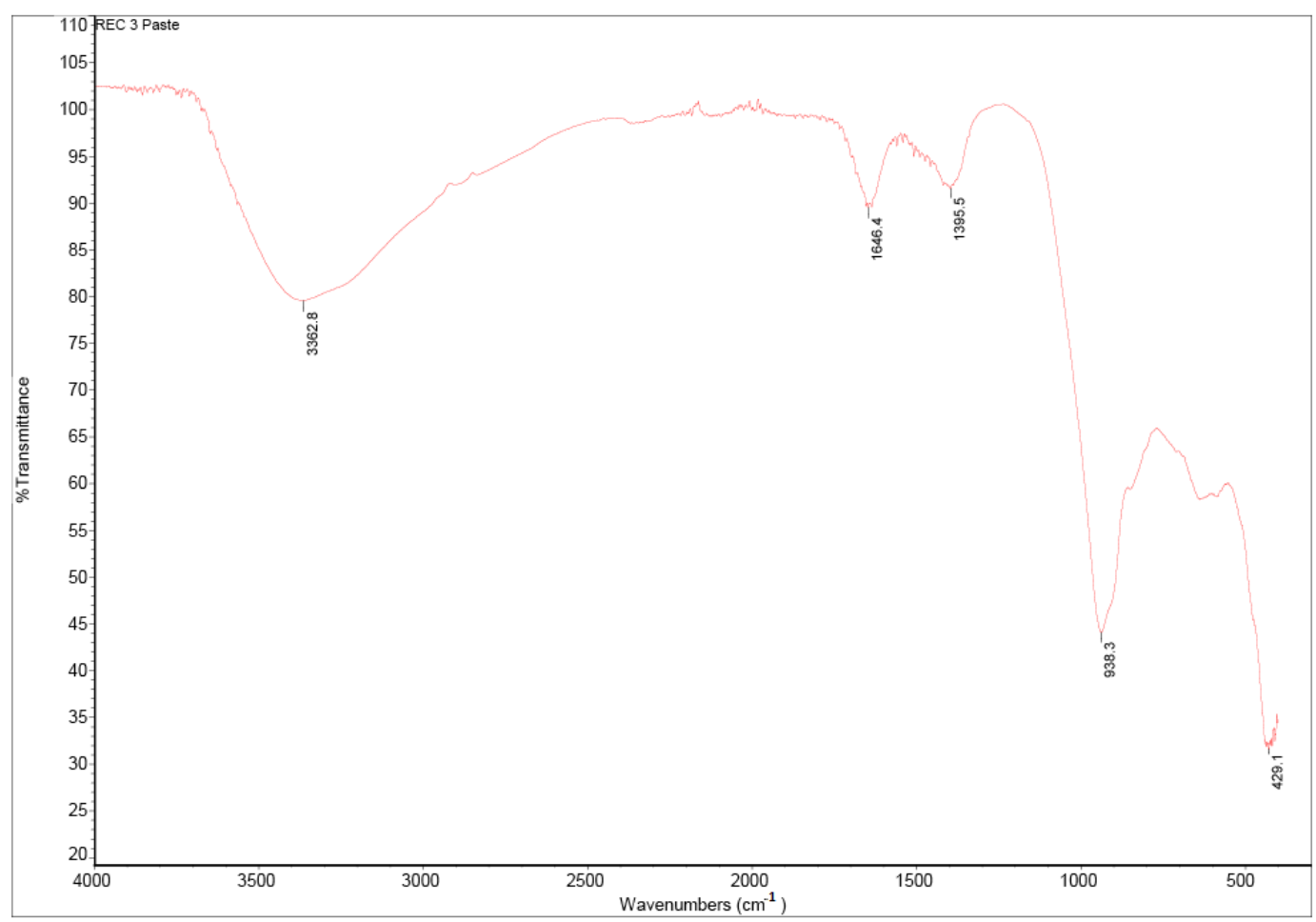

Figure 13. FTIR analysis for REC 3.

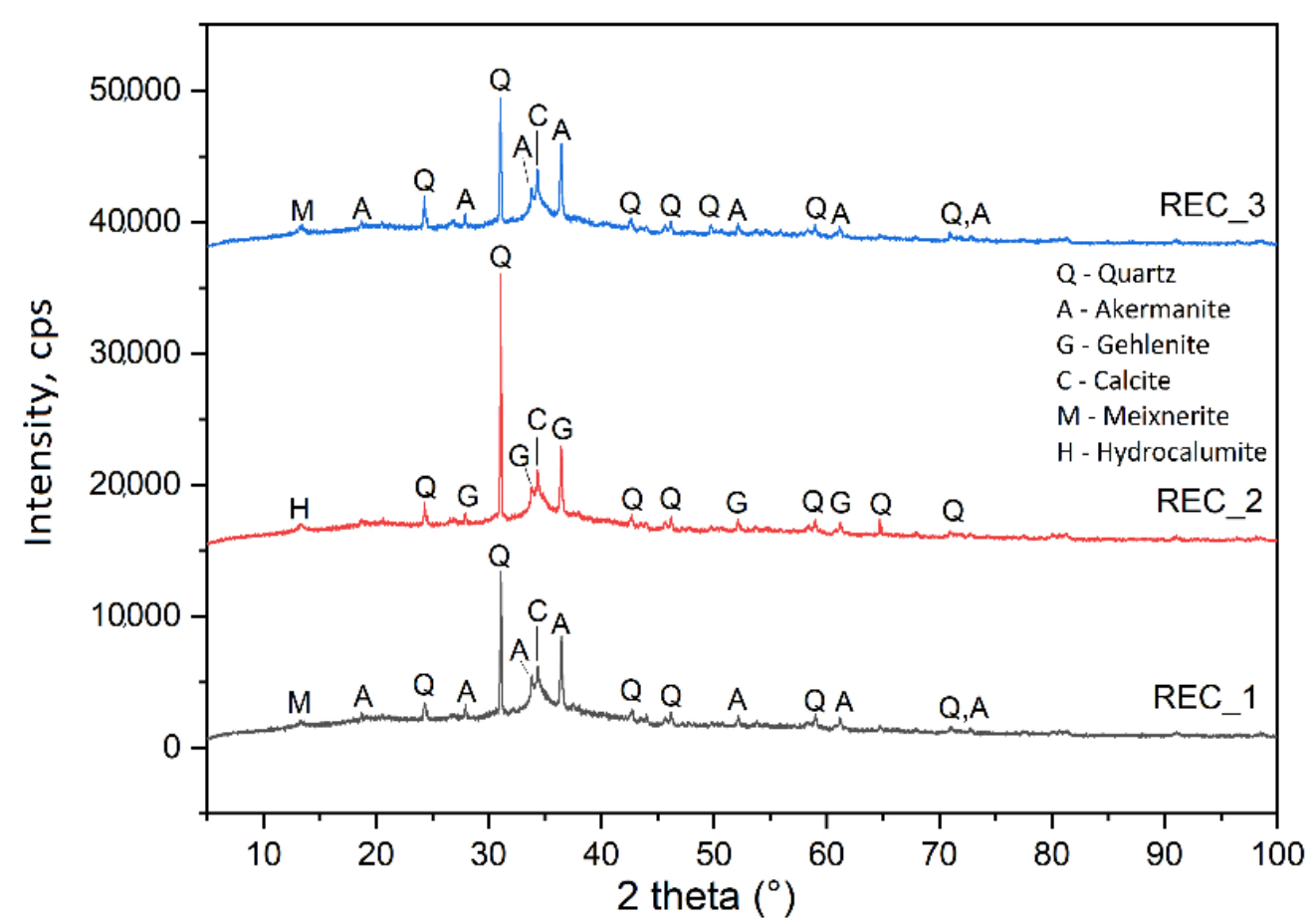

Figure 14. Mineralogical composition determined by X-ray diffraction (XRD) of prepared alkali activated pastes.

\subsubsection{Ftir Analysis}

Figures 11-13 show the resulting curves of FTIR analysis of individual mixtures of alkali-activated pastes.

In the area of 3360 and $1640 \mathrm{~cm}^{-1}$, the water stress $(\mathrm{O}-\mathrm{H})$ and deformation $(\mathrm{H}-\mathrm{OH})$ bands are identified. These areas are caused by the presence of chemically bounded water in the hydrated alkali-activated materials in different spectra. Absorption bands 
around 1395 and $875 \mathrm{~cm}^{-1}$ correspond to $\mathrm{O}-\mathrm{C}-\mathrm{O}$ vibrations in carbonates. The main absorption band of the reaction product is located at around $935 \mathrm{~cm}^{-1}$ in all mixtures, which are assigned to the asymmetric stretching vibration of $\mathrm{Si}-\mathrm{O}-\mathrm{T}$ ( $\mathrm{T}=$ tetrahedral $\mathrm{Si}$ or $\mathrm{Al}$ ) terminal (non-bridging) bonds, indicating that the main reaction product is a chain structured C-(A)-S-H type gel. The area moving around $430 \mathrm{~cm}^{-1}$ represents bonds (Si-O-Si and O-Si-O) [20,33,54-57].

The main difference between specimens placed indoors and outdoors is that the exterior specimens have an added peak in the area of 870 [58] and $712 \mathrm{~cm}^{-1}$ representing carbonate bonds. There are also differences in absorbance, especially with carbonate peaks in the region of $1410 \mathrm{~cm}^{-1}$, when the peaks in the exterior specimens are much larger. The manual "IR Spectral Interpretation, Thermo SCIENTIFIC" was used for initial identification. However, in these materials, there was a large variance of values between the graphical and textual evaluation of the peak in the range of $1420 \pm 20 \mathrm{~cm}^{-1}$. Therefore, analysis of pure limestone was performed with the resulting peaks at 1395,871 and $712 \mathrm{~cm}^{-1}$. The slight variance of values, especially in the area of the 1395-1410 peak, can be caused by the accuracy of the instrument measurement and possible other constraints that may affect the location of the peak. There are major peaks in this area for both sodium carbonate and calcium carbonate, and this can affect the location of the peak.

\subsubsection{Xrd Analysis}

The X-ray diffraction results of the alkali activated pastes are shown in Figure 14.

XRD analysis provided interesting results when comparing between individual mixtures. The mineral Akermanite was detected in the pastes REC 1 and REC 3, while the mineral Gehlenite was detected in the mixture REC 2. Although these are similar minerals that occur in the same 2 theta $^{\circ}$ area and in some cases these minerals occur as AkermniteGehlenite mineral, the question is how significantly the individual components of the composite (and their ratios) affect the resulting hydration products. REC 1 contained minerals Meixnerite and Sylvite, which were found to be present in the CPBD, while in mixtures REC 2 and REC 3, mineral Hydrocalumite was found, containing, among other things, chlorine. Therefore, it can be assumed that the chlorine contained in the CPBD was incorporated into the structure of this mineral.

\subsection{Grassland and Changes in Substrate Properties}

After the completion of the in situ test and the removal of the analysis beams, substrate samples were taken from each series, leachates were prepared and the $\mathrm{pH}$ of the experiment was measured. All boxes were drainless.

According to the authors [59], the optimal $\mathrm{pH}$ for a lawn is 6-7 $\mathrm{pH}$. In Series 1, the $\mathrm{pH}$ increased to the optimum. However, the storage length was short. In contrast, for the specimens from other series, the $\mathrm{pH}$ kept increasing above $7 \mathrm{pH}$. In the long run, increasing $\mathrm{pH}$ could slow growth [60]. Drainless boxes were chosen for the experiment. When stored in the natural environment, where there would be a gradual seepage into the soil, a smaller increase in $\mathrm{pH}$ can be expected. The $\mathrm{pH}$ values increased and also according to the proportion of activator, the increases of REC 1 were higher than of REC 3, Table 12.

Table 12. $\mathrm{pH}$ measurement results.

\begin{tabular}{ccccc}
\hline & pH Series 1 & pH Series 2 & pH Series 3 & pH Series 4 \\
\hline REC 1 & 6.36 & 8.53 & 8.28 & 7.72 \\
REC 2 & 5.78 & 7.83 & 8.05 & 7.34 \\
REC 3 & 5.38 & 7.52 & 8.04 & 7.01 \\
Substrate before placing the beams & 5.11 & 5.61 & 4.96 & 5.80 \\
\hline
\end{tabular}

The condition of the grass was continuously checked in all four series. Despite the increasing $\mathrm{pH}$, no significant deviations in the growth of the grass around the beam were observed, not even in Series 3, which included all vegetation phases. The inspection of 
the condition of the roots showed a well-rooted root ball. The condition of the grass can be seen in Figures 15 and 16. Potassium, which is important for plant growth, could have contributed to the good condition of the grassland [61]. Orientational analyses of the extracts of beams (beams that were not stored in boxes) ranged from 200 to $250 \mathrm{mg} / \mathrm{kg}$ for individual mixtures.

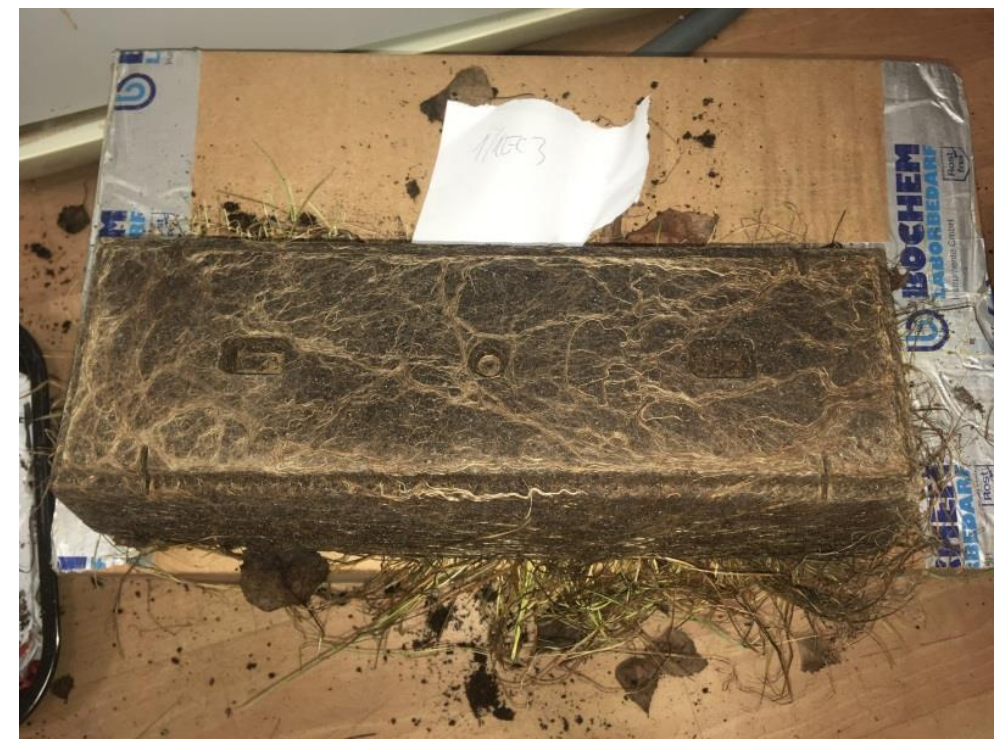

Figure 15. Root ball in Series 3 (B. Vojvodikova).

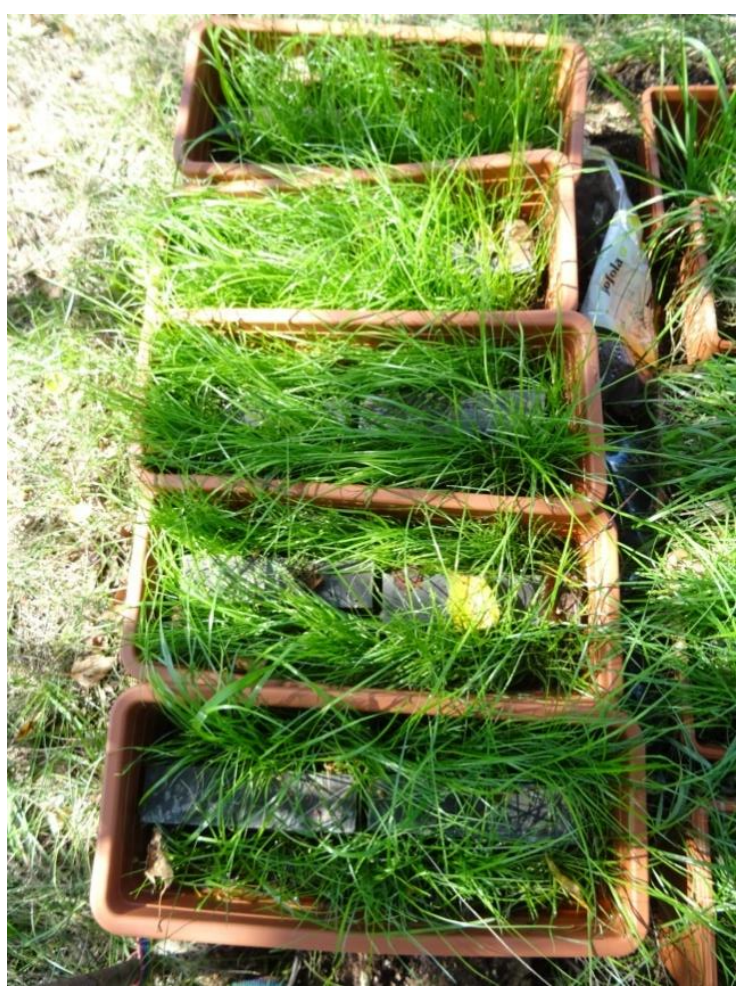

Figure 16. Grass condition in Series 2 after 30 days (B. Vojvodikova).

The garden architecture element is in direct interaction with the plants. No significant negative impacts have been demonstrated in the research as outlined above. When comparing the reference boxes without the beams, it was observed that the grass cover is weaker and less developed than in the boxes with the beams. A possible answer is given 
by [43], where plants were grown directly in containers made of alkali-activated material. However, these did not contain CBPD. Potassium availability is also important [61]. Yet this cannot be regarded as a clear-cut explanation. In the next phase of the research, the long-term effect will have to be investigated without affecting the size of the pot (field study in a prepared bed). If this is a long-term positive effect without negatively affecting the physical and mechanical properties of the beams, this would be positive in terms of the use of CBPD. Finding answers to these questions will be part of further research.

\section{Conclusions}

Present research is generally focused on the possible processing of secondary raw materials in construction as well as on the possible use of alkaline activation. This experiment is unique in that it combines the effort to apply CBPD and fly ash after denitrification in an alkali-activated system, and the results are compared with conditions to produce garden architecture elements.

This article introduces the results of the introductory part of the research. Here is a summary of the findings with reference to the continuation of research activities.

Products containing CBPD are usable in terms of their physical-mechanical properties for practical use in curbs for garden architecture. These properties were verified with test specimens placed in a laboratory environment and in situ. The results were compared with the required values given in the standard ČSN EN 1340. The mixtures did not pass the scaling resistance test since they will be used as road curbs. For garden architecture, this resistance is not required. To expand the possibility of employing these curbs for wider use, research should continue to use protective coatings which could improve the results of the scaling resistance test.

As garden architecture elements are also an aesthetic issue, it is essential to pay attention to the surface of the product. When testing Series 3 , shrinkage cracks were found on the test specimens. Samples for computed tomography were prepared from this series. Samples for pore structure analysis of mixtures were also prepared. These results have yet to be evaluated and will be given attention in follow-up research. Attention will also be paid to possible surface treatments that could improve scaling resistance. Abrasiveness will be determined on the prepared mixtures.

To increase the positive effects on the environment, the possibility of using a combination of fly ash slag and CBPD as a cement substitute has been confirmed. In the production of beams from cement, the weight of cement represents $21 \%$ of the total weight. If we perform a hypothetical calculation for 1 ton of curbs, assuming that the cement is fully replaced by secondary raw materials, we save $210 \mathrm{~kg}$ of cement. A special positive effect is then found for the use of CBPD. For REC1, the proportion of CBPD was 3.3\% of the total weight. We can therefore state that for 1 ton of beams, it is $33 \mathrm{~kg}$ of CBPD which would be used and not landfilled.

Author Contributions: L.P.-Conceptualization, methodology, formal analysis, investigation, resources, writing - original draft preparation. B.V.-Conceptualization, methodology, formal analysis, investigation, resources, writing—original draft preparation, writing—review and editing, project administration. J.B.-Methodology, investigation, resources, supervision. All authors have read and agreed to the published version of the manuscript.

Funding: This research was funded by H2020 Marie Skłodowska-Curie Actions, grant number 7348336.

Acknowledgments: The authors would like to thank the Department of Thermal Engineering from VSB-Technical University of Ostrava for performing XRD and XRF analyzes.

Conflicts of Interest: The authors declare that they have no known competing financial interests or personal relationships that could have appeared to influence the work reported in this paper. 


\section{References}

1. Liu, J.; Zhang, S.; Wagner, F. Exploring the driving forces of energy consumption and environmental pollution in China's cement industry at the provincial level. J. Clean. Prod. 2018, 184, 274-285. [CrossRef]

2. Adeyanju, E.; Okeke, C.A.U. Exposure effect to cement dust pollution: A mini review. SN Appl. Sci. 2019, 1, 1572. [CrossRef]

3. Abdul-Wahab, S.A. Impact of fugitive dust emissions from cement plants on nearby communities. Ecol. Model. 2006, 195, 338-348. [CrossRef]

4. Salami, A.; Farounbi, A.; Muoghalu, J. Effect of cement production on vegetation in a part of southwestern Nigeria. Tanzan J. Sci. 2004, 28, 69-82. [CrossRef]

5. Chen, C.; Habert, G.; Bouzidi, Y.; Jullien, A. Environmental impact of cement production: Detail of the different processes and cement plant variability evaluation. J. Clean. Prod. 2010, 18, 478-485. [CrossRef]

6. Tkaczewska, E. The influence of cement bypass dust on the properties of cement curing under normal and autoclave conditions. Struct. Environ. 2019, 11, 5-22. [CrossRef]

7. Altwair, N.; Kabir, S. Reducing Environmental Impacts through Green Concrete Technology. In Proceedings of the 3rd Technology and Innovation for Sustainable Development International Conference (TISD2010), Khon Kaen, Thailand, 4-6 March 2010; Faculty of Engineering, Khon Kaen University: Khon Kaen, Thailand, 2010.

8. Konsta-Gdoutos, M.S.; Shah, S.P. Hydration and properties of novel blended cements based on cement kiln dust and blast furnace slag. Cem. Concr. Res. 2003, 33, 1269-1276. [CrossRef]

9. Ahmari, S.; Zhang, L. Utilization of cement kiln dust (CKD) to enhance mine tailings-based geopolymer bricks. Constr. Build. Mater. 2013, 40, 1002-1011. [CrossRef]

10. Sikorova, V. Methods of Using Cement Kiln By-Pass Dust in Building Materials Technology. Master's Thesis, Brno, Czech Republic, 2019.

11. Pavía, S.; Regan, D. Influence of cement kiln dust on the physical properties of calcium lime mortars. Mater. Struct. 2009, 43, 381-391. [CrossRef]

12. Adaska, W.S.; Taubert, D.H. Beneficial Uses of Cement Kiln Dust. In Proceedings of the 2008 IEEE Cement Industry Technical Conference Record, Miami, FL, USA, 18-22 May 2008. [CrossRef]

13. Khudhair, M.; Elharfi, A. Formulation of the cement kiln dust (CKD) in concrete: Studies of the physical-chemical and mechanical properties. Int. J. ChemTech Res. 2016, 9, 695-704.

14. Mostafa, H.M.; Rashed, E.M.; Mostafa, A.H. Utilizations of by-pass kiln dust for treatment of tanneries effluent wastewater. In Proceedings of the 9th International Water Technology Conference, WTC9 2005, Sharm El-Sheikh, Egypt, 17-20 March 2005; pp. 133-141.

15. Dyer, T.; Halliday, J.E.; Dhir, R.K. An investigation of the hydration chemistry of ternary blends containing cement kiln dust. J. Mater. Sci. 1999, 34, 4975-4983. [CrossRef]

16. Seto, K.E.; Churchill, C.J.; Panesar, D.K. Influence of fly ash allocation approaches on the life cycle assessment of cement-based materials. J. Clean. Prod. 2017, 157, 65-75. [CrossRef]

17. Marjanović, N.; Komljenovic, M.; Baščarević, Z.; Nikolić, V. Comparison of Two Alkali-activated Systems: Mechanically Activated Fly Ash and fly Ash-blast Furnace Slag Blends. Procedia Eng. 2015, 108, 231-238. [CrossRef]

18. Ravikumar, D.; Peethamparan, S.; Neithalath, N. Structure and strength of NaOH activated concretes containing fly ash or GGBFS as the sole binder. Cem. Concr. Compos. 2010, 32, 399-410. [CrossRef]

19. Van Deventer, J.S.; Provis, J.; Duxson, P. Technical and commercial progress in the adoption of geopolymer cement. Miner. Eng. 2012, 29, 89-104. [CrossRef]

20. Gao, X.; Yu, Q.; Brouwers, H. Properties of alkali activated slag-fly ash blends with limestone addition. Cem. Concr. Compos. 2015, 59, 119-128. [CrossRef]

21. Puertas, F.; Palacios, M.; Manzano, H.; Dolado, J.S.; Rico, A.; Rodríguez, J. A model for the C-A-S-H gel formed in alkali-activated slag cements. J. Eur. Ceram. Soc. 2011, 31, 2043-2056. [CrossRef]

22. Oh, J.E.; Monteiro, P.J.; Jun, S.S.; Choi, S.; Clark, S. The evolution of strength and crystalline phases for alkali-activated ground blast furnace slag and fly ash-based geopolymers. Cem. Concr. Res. 2010, 40, 189-196. [CrossRef]

23. Kumar, S.; Kumar, R.; Mehrotra, S.P. Influence of granulated blast furnace slag on the reaction, structure and properties of fly ash based geopolymer. J. Mater. Sci. 2010, 45, 607-615. [CrossRef]

24. Marjanović, N.; Komljenovic, M.; Baščarević, Z.; Nikolic, V.; Petrović, R. Physical-mechanical and microstructural properties of alkali-activated fly ash-blast furnace slag blends. Ceram. Int. 2015, 41, 1421-1435. [CrossRef]

25. Samson, G.; Cyr, M.; Gao, X.X. Formulation and characterization of blended alkali-activated materials based on flash-calcined metakaolin, fly ash and GGBS. Constr. Build. Mater. 2017, 144, 50-64. [CrossRef]

26. Wang, A.; Zheng, Y.; Zhang, Z.; Liu, K.; Li, Y.; Shi, L.; Sun, D. The Durability of Alkali-Activated Materials in Comparison with Ordinary Portland Cements and Concretes: A Review. Engineering 2020, 6, 695-706. [CrossRef]

27. Lodeiro, I.G.; Jimenez, A.M.F.; Palomo, A.; Macphee, D. Effect on fresh C-S-H gels of the simultaneous addition of alkali and aluminium. Cem. Concr. Res. 2010, 40, 27-32. [CrossRef]

28. Garcia-Lodeiro, I.; Palomo, A.; Jimenez, A.M.F.; Macphee, D. Compatibility studies between N-A-S-H and C-A-S-H gels. Study in the ternary diagram $\mathrm{Na}_{2} \mathrm{O}-\mathrm{CaO}-\mathrm{Al}_{2} \mathrm{O}_{3}-\mathrm{SiO}_{2}-\mathrm{H}_{2} \mathrm{O}$. Cem. Concr. Res. 2011, 41, 923-931. [CrossRef] 
29. Palacios, M.; Puertas, F. Effect of shrinkage-reducing admixtures on the properties of alkali-activated slag mortars and pastes. Cem. Concr. Res. 2007, 37, 691-702. [CrossRef]

30. Bakharev, T. Thermal behaviour of geopolymers prepared using class F fly ash and elevated temperature curing. Cem. Concr. Res. 2006, 36, 1134-1147. [CrossRef]

31. Lee, N.K.; Lee, H.K. Setting and mechanical properties of alkali-activated fly ash/slag concrete manufactured at room temperature. Constr. Build. Mater. 2013, 47, 1201-1209. [CrossRef]

32. Chang, J.J.; Yeih, W.; Hung, C.C. Effects of gypsum and phosphoric acid on the properties of sodium silicate-based alkali-activated slag pastes. Cem. Concr. Compos. 2005, 27, 85-91. [CrossRef]

33. Ismail, I.; A Bernal, S.; Provis, J.L.; Hamdan, S.; Van Deventer, J.S.J. Microstructural changes in alkali activated fly ash/slag geopolymers with sulfate exposure. Mater. Struct. 2012, 46, 361-373. [CrossRef]

34. Procházka, L.; Boháčová, J. Effect of Admixtures on Durability Characteristics of Fly Ash Alkali-activated Material. Emerg. Sci. J. 2020, 4, 493-502. [CrossRef]

35. Kotouč Štramberk. 2018. Available online: https:/ / www.cemix.cz/kotouc/cz (accessed on 12 January 2018).

36. Penta Chemical Unlinited-Chemikalie. Available online: https://www.pentachemicals.eu/chemikalie (accessed on 12 January 2018).

37. ČSN EN 196-1 Methods of Testing Cement_Part 1: Determination of Strength; Office for Technical Standardization, Metrology and State Testing: Prague, Czech Republic, 2005; pp. 5-40.

38. Boháčová, J. Study of Influence of Different Types of Fillers on Properties of Geopolymer Systems Based on Alkali Activated Slags; VŠB-TUO: Ostrava, Czech Republic, 2008.

39. Bohacova, J.; Janalík, L. Preparation and Verification of Properties of Alkali-Activated Composite. Solid State Phenom. 2019, 296, 209-214. [CrossRef]

40. Koňařík, J. Influence of Activator on Basic Properties of Alkali Activated Systems; VŠB-TUO: Ostrava, Czech Republic, 2014.

41. Mec, P.; Boháčová, J.; Závrský, P. Testing of Possible Use of Fine-Grained Alkali Activated Composites in the Construction Industry. Mater. Sci. Forum 2016, 865, 47-52. [CrossRef]

42. ČSN EN 1340 Concrete Kerb Units-Requirements and Test Methods; Office for Technical Standardization, Metrology and State Testing: Prague, Czech Republic, 2004.

43. Szechyńska-Hebda, M.; Marczyk, J.; Ziejewska, C.; Hordyńska, N.; Mikuła, J.; Hebda, M. Optimal Design of pH-neutral Geopolymer Foams for Their Use in Ecological Plant Cultivation Systems. Materials 2019, 12, 2999. [CrossRef] [PubMed]

44. ČSN EN 196-3 Methods of Testing Cement-Part 3: Determination of Setting Times and Soundness; Office for Technical Standardization, Metrology and State Testing: Prague, Czech Republic, 2006; pp. 5-40.

45. ČSN 722452 Frost Resistance Test of Mortar; Office for Technical Standardization, Metrology and State Testing: Prague, Czech Republic, 1970; Classifier 722452.

46. ČSN 731326 Determination of the Resistance of the Surface of Cement Concrete to the Action of Water and Scaling Resistance; Office for Technical Standardization, Metrology and State Testing: Prague, Czech Republic, 1985.

47. Shahrajabian, F.; Behfarnia, K. The effects of nano particles on freeze and thaw resistance of alkali-activated slag concrete. Constr. Build. Mater. 2018, 176, 172-178. [CrossRef]

48. Jozwiak Niedzwiedzka, D. Scaling resistance and resistivity of concretes containing fluidized bed combustion fly ash. In Proceedings of the 3rd International Symposium on Non-Traditional Cement \&Concrete, Brno, Czech Republic, 10-12 June 2008; pp. 348-355, ISBN 978-80-214-3642-8.

49. Matalkah, F.; Soroushian, P. Freeze thaw and deicer salt scaling resistance of concrete prepared with alkali aluminosilicate cement. Constr. Build. Mater. 2018, 163, 200-213. [CrossRef]

50. Provis, J.L.; Deventer, J.S.J. Geololymers, Structure, Processing, Properties and Industrial Applications; Woodhead Publishing Limited: Sawston, UK, 2009; ISBN 978-1-84569-449-4.

51. Mec, P.; Boháčová, J.; Turicová, M. Thermal Analysis Application in Study of Alkali-Activated Blast Furnace Slag. Appl. Mech. Mater. 2016, 835, 547-553. [CrossRef]

52. Kashani, A.; Ngo, T.; Walkley, B.; Mendis, P. Thermal performance of calcium-rich alkali-activated materials: A microstructural and mechanical study. Constr. Build. Mater. 2017, 153, 225-237. [CrossRef]

53. Burduhos Nergis, D.D.; Abdullah, M.M.A.B.; Sandu, A.V.; Vizureanu, P. XRD and TG-DTA Study of New Alkali Activated Materials Based on Fly Ash with Sand and Glass Powder. Materials 2020, 13, 343. [CrossRef]

54. Ismail, I.; A Bernal, S.; Provis, J.; Nicolas, R.S.; Hamdan, S.; van Deventer, J.S. Modification of phase evolution in alkali-activated blast furnace slag by the incorporation of fly ash. Cem. Concr. Compos. 2014, 45, 125-135. [CrossRef]

55. Puertas, F.; Jimenez, A.M.F. Mineralogical and microstructural characterisation of alkali-activated fly ash/slag pastes. Cem. Concr. Compos. 2003, 25, 287-292. [CrossRef]

56. De Gutierrez, R.M.; Robayo, R.A.; Gordillo, M. Natural pozzolan-and granulated blast furnace slag-based binary geopolymers. Materiales de Construcción 2016, 66, e077. [CrossRef]

57. Silva, I.; Castro-Gomes, J.P.; Albuquerque, A. Effect of immersion in water partially alkali-activated materials obtained of tungsten mine waste mud. Constr. Build. Mater. 2012, 35, 117-124. [CrossRef] 
58. Castaldelli, V.N.; Akasaki, J.L.; Melges, J.L.; Tashima, M.M.; Soriano, L.; Borrachero, M.V.; Monzó, J.; Payá, J. Use of Slag/Sugar Cane Bagasse Ash (SCBA) Blends in the Production of Alkali-Activated Materials. Materials 2013, 6, 3108-3127. [CrossRef] [PubMed]

59. Goulding, K.W.T. Soil acidification and the importance of liming agricultural soils with particular reference to the United Kingdom. Soil Use Manag. 2016, 32, 390-399. [CrossRef] [PubMed]

60. Haling, R.E.; Simpson, R.J.; Culvenor, R.A.; Lambers, H.; Richardson, A.E. Effect of soil acidity, soil strength and macropores on root growth and morphology of perennial grass species differing in acid-soil resistance. Plant Cell Environ. 2010, 34, 444-456. [CrossRef]

61. Wakeel, A.; Farooq, M.; Qadir, M.; Schubert, S. Potassium Substitution by Sodium in Plants. Crit. Rev. Plant Sci. 2011, 30, 401-413. [CrossRef] 